\title{
Environmental Management of Legionella in Domestic Water Systems: Consolidated and Innovative Approaches for Disinfection Methods and Risk Assessment
}

\author{
Emanuele Luigi Sciuto $^{1} \mathbb{D}$, Pasqualina Laganà ${ }^{2} \mathbb{D}$, Simona Filice ${ }^{3} \mathbb{D}$, Silvia Scalese ${ }^{3}$, , Sebania Libertino ${ }^{3} \mathbb{D}$, \\ Domenico Corso $^{3}$, Giuseppina Faro ${ }^{4}$ and Maria Anna Coniglio $1,5, *$ iD
}

Citation: Sciuto, E.L.; Laganà, P.; Filice, S.; Scalese, S.; Libertino, S.; Corso, D.; Faro, G.; Coniglio, M.A. Environmental Management of Legionella in Domestic Water Systems: Consolidated and Innovative Approaches for Disinfection Methods and Risk Assessment. Microorganisms 2021, 9, 577. https://doi.org/ 10.3390/microorganisms 9030577

Academic Editors: Janet E. Stout and Julianne L. Baron

Received: 22 February 2021

Accepted: 9 March 2021

Published: 11 March 2021

Publisher's Note: MDPI stays neutral with regard to jurisdictional claims in published maps and institutional affiliations.

Copyright: (c) 2021 by the authors. Licensee MDPI, Basel, Switzerland. This article is an open access article distributed under the terms and conditions of the Creative Commons Attribution (CC BY) license (https:// creativecommons.org/licenses/by/ $4.0 /)$.
1 Azienda Ospedaliero Universitaria Policlinico “G. Rodolico-San Marco", Via Sofia 78, 95123 Catania, Italy; e.l.sciuto@gmail.com

2 Regional Reference Laboratory of Clinical and Environmental Surveillance of Legionellosis, Messina, Department of Biomedical and Dental Sciences and Morphofunctional Imaging, University of Messina, Torre Biologica 3p, AOU ‘G. Martino, Via C. Valeria, s.n.c., 98125 Messina, Italy; plagana@unime.it

3 Istituto per la Microelettronica e Microsistemi-Consiglio Nazionale delle Ricerche (CNR-IMM), Ottava Strada 5, 95121 Catania, Italy; simona.filice@imm.cnr.it (S.F.); silvia.scalese@imm.cnr.it (S.S.); sebania.libertino@imm.cnr.it (S.L.); domenico.corso@imm.cnr.it (D.C.)

4 Azienda Sanitaria Provinciale di Catania, Via S. Maria La Grande 5, 95124 Catania, Italy; giuseppina.faro@aspct.it

5 Regional Reference Laboratory of Clinical and Environmental Surveillance of Legionellosis, Catania, Department of Medical and Surgical Sciences and Advanced Technologies "G.F. Ingrassia", University of Catania, Via Sofia 87, 95123 Catania, Italy

* Correspondence: ma.coniglio@unict.it

\begin{abstract}
Legionella is able to remain in water as free-living planktonic bacteria or to grow within biofilms that adhere to the pipes. It is also able to enter amoebas or to switch into a viable but not culturable (VBNC) state, which contributes to its resistance to harsh conditions and hinders its detection in water. Factors regulating Legionella growth, such as environmental conditions, type and concentration of available organic and inorganic nutrients, presence of protozoa, spatial location of microorganisms, metal plumbing components, and associated corrosion products are important for Legionella survival and growth. Finally, water treatment and distribution conditions may affect each of these factors. A deeper comprehension of Legionella interactions in water distribution systems with the environmental conditions is needed for better control of the colonization. To this purpose, the implementation of water management plans is the main prevention measure against Legionella. A water management program requires coordination among building managers, health care providers, and Public Health professionals. The review reports a comprehensive view of the state of the art and the promising perspectives of both monitoring and disinfection methods against Legionella in water, focusing on the main current challenges concerning the Public Health sector.
\end{abstract}

Keywords: Legionella; water systems; Water Safety Plan; disinfection methods; emerging technologies

\section{Introduction}

Legionella colonization of building potable water systems implies many Public Health concerns, especially for more fragile persons (elderly adults, smokers or people with weakened immune systems), which are particularly susceptible to the infection and at risk for developing clinical complications and respiratory failure. Obviously, as the population ages, the health impact on 'at risk' groups of legionellosis is likely to continue to increase.

Isolation and identification of Legionella from the environment is crucial for the management of environmental and clinical prevention, as well as for epidemiological purposes and for outbreak investigations. Culture methods are the gold standard for the detection of Legionella in environmental samples. Hazard analysis is also useful within the context 
of a control risk management plan. In addition, the adoption of chemical or physical disinfection methods is essential to contain the contamination.

This review focuses on historic, current, and emerging monitoring and disinfection methods against Legionella. State of the art and promising perspectives are reported. Moreover, challenges facing health care professionals, building managers, and the Public Health sector are discussed.

\section{Methods}

Search for literature was carried out using the keywords: 'Legionella' OR 'Legionnaires' Disease' NEAR 'prevention' AND 'water systems' AND 'disinfection methods' NEAR 'Legionella' AND 'risk assessment' AND 'Water Safety Plan'. The search included published papers between 1980 and 2020, and it was conducted in relevant biomedical and engineering databases: ACS Publications, Elsevier, JSTOR, PubMed, SDOS, and Wiley Online Library. US and European technical reports and guidelines for the prevention of legionellosis were also included. Inclusion criteria were studies about: (i) growth and survival of legionellae in water systems, (ii) effectiveness of conventional and emerging treatment technologies under in vitro conditions and after follow up in real conditions, (iii) water sampling and emerging detection methods, and (iv) water systems management programs.

The literature review was divided into four main parts to evaluate the following aspects of environmental management of Legionella in domestic water systems: (i) factors that regulate Legionella growth and survival, (ii) disinfection methods, (iii) monitoring methods, and (iv) risk assessment.

As reported in Figure 1, after the initial search through databases, n. 300 records were identified for further review. Additionally, n. 11 records (e.g., EU regulations, technical reports, guidelines, kit datasheets, etc.) were identified through other web sources. Once the duplicates were removed, a total of $n .98$ records were excluded because they were out of the topic. Finally, among the full-text articles, n. 166 were confirmed because they matched the inclusion criteria.
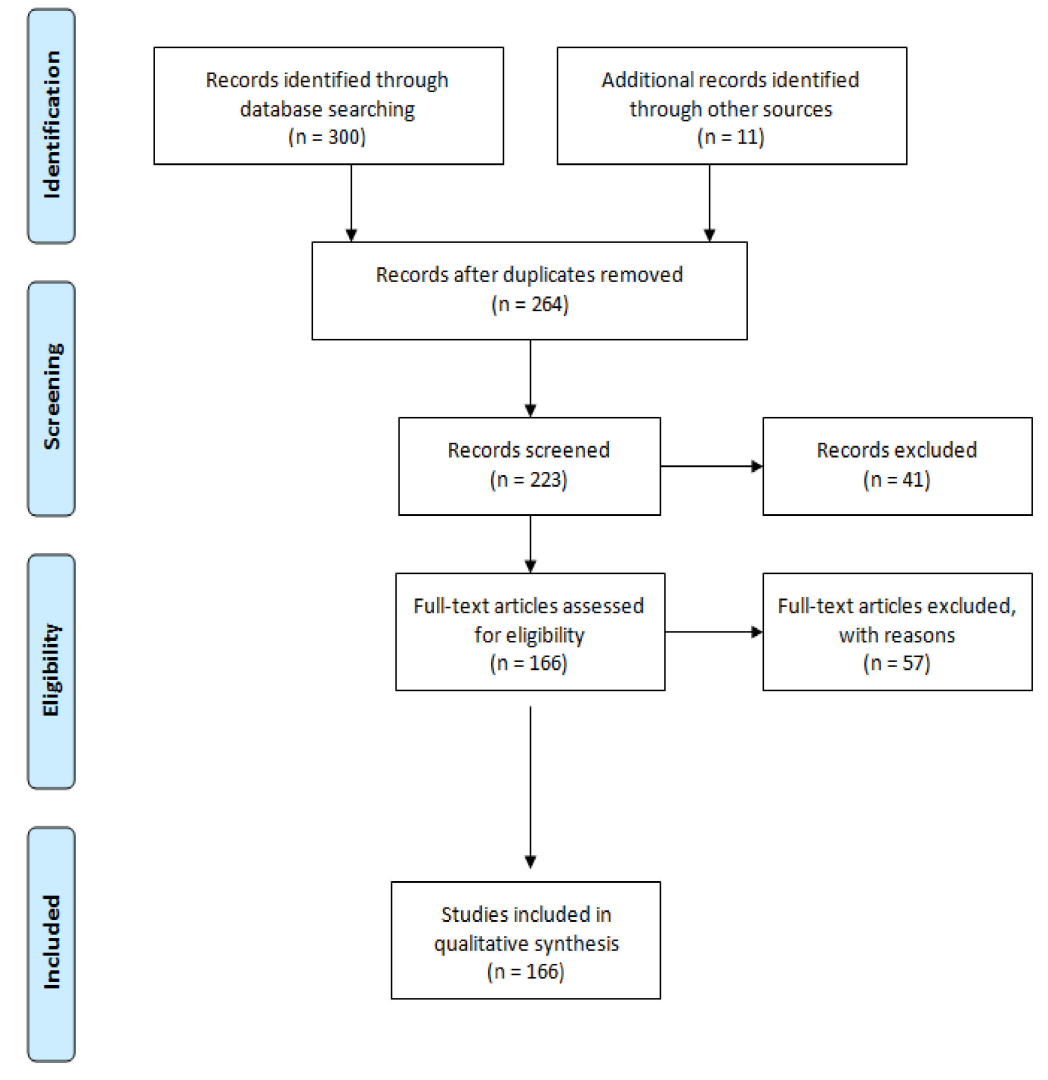

Figure 1. Flow diagram. 
Each article was evaluated with respect to the environmental factors related to the growth of Legionella in water systems, if the management of the water distribution system was associated with the control of Legionella, and if the management strategies were adequately tested for effectiveness and/or accuracy.

\section{Factors Related to the Growth and Survival of Legionellae and the Management of Environmental Prevention}

Legionellae are ubiquitous in natural and man-made water systems. A few, and especially Legionella longbeacheae, are also isolated from non-aquatic habitats such as potting soil and compost [1]. The correlation between Legionella colonization of a water system and the risk of acquiring the disease has been well established. When colonization occurs within a water system, abatement of Legionella is difficult and generally eradication is not possible because the bacterium has found the optimal environmental conditions and because it can activate surviving strategies.

Favorable conditions for the multiplication of Legionella in water systems include water temperature, stagnation, and the presence of free-living protozoa, which protect intracellular bacteria from adverse environmental conditions, including water disinfection procedures. Scale and organic sediment also provide nutrients for the formation of biofilms in which legionellae can persist for a long time, sometimes also for decades.

\subsection{Water Temperature}

The water temperature regime plays an important role in Legionella survival and growth. Legionella pneumophila, in particular, multiplies at temperatures between $25{ }^{\circ} \mathrm{C}$ and $42{ }^{\circ} \mathrm{C}$, with an optimal growth temperature of $35^{\circ} \mathrm{C}$ [2]. Thus, as indicated by several guidelines and technical reports, a key control measure of distribution systems colonization is to maintain elevated temperatures for the hot water and low temperatures for the cold water. The Centers for Disease Control and Prevention (CDC) guidelines for prevention of waterborne microbial contamination within the distribution system recommend to maintain hot water temperature at the return preferably at $\geq 51{ }^{\circ} \mathrm{C}$, and maintain cold water temperature at $<20^{\circ} \mathrm{C}$ [3]. The European Technical Guidelines for the prevention, control, and investigation of infections caused by Legionella species [4] underline that avoiding water temperatures of between $20-25^{\circ} \mathrm{C}$ and $50-55^{\circ} \mathrm{C}$ in any part of a water system for any period of time is an important factor in controlling the risk. Finally, Italian Guidelines for the prevention and control of legionnaires' disease [5] suggest a temperature of $\geq 60{ }^{\circ} \mathrm{C}$ at the water heater and a minimal water temperature of $50{ }^{\circ} \mathrm{C}$ across the network. However, in large buildings with complex plumbing systems, it can be difficult to reach these temperatures. On the other hand, elevated water temperatures accelerate disinfectant decay (e.g., chloramines and chlorine) [6,7] and predispose hot water systems to deteriorating microbial water quality [8]. Finally, when it is possible to achieve and maintain high water temperatures, the risk of scalding increases significantly. To minimize this risk, the already mentioned CDC guidelines suggest to install preset thermostatic valves (TMVs) in point-of-use fixtures which, in turn, may cause some drawbacks.

A TMV is a valve that blends hot water with cold water to ensure safe, constant water temperatures, typically between $38^{\circ} \mathrm{C}$ and $46^{\circ} \mathrm{C}$, to water outlets. The TMV can be fitted between the hot and cold supply pipework and the outlet tap, or directly at the tap. The mixed water downstream of a TMV may provide an environment favorable to Legionella colonization, thus increasing the risk of exposure. Obviously, this needs to be managed. TMVs are very important for scald protection for anyone and particularly important for the very young, such as in schools and childcare facilities, and for the elderly and infirm, such as in care homes and hospitals. On the other hand, these settings-and in particular the hospitals and care homes-are of major concerns because they host persons particularly susceptible to the infection and at risk for developing severe clinical complications. Therefore, the use of TMVs should be decided by preliminary assessing the risk of scalding against the risk of infection from Legionella: If the risk of scalding is insignificant, TMVs are not required. Otherwise, where they are required, TMVs routine maintenance must 
be carried out by competent persons in accordance with the manufacturer's instructions. Maintenance implies regular inspection, cleaning, descaling, and disinfection of any filters associated with each TMV. Finally, several cautions should be considered when TMVs are installed. First of all, they should be fitted as close as possible to the point of use in order to minimize the amount of stored blended water and, in turn, to avoid the risk of Legionella colonization. Secondly, a single TMV serving multiple outlets can increase this risk. For this reason, prior to its installation, the system parameters need to be checked against the working parameters of the TMV in order to decide how many outlets it could serve [9].

When it is not possible to maintain hot water temperatures above $50{ }^{\circ} \mathrm{C}$ and buildings cannot be retrofitted for TMVs, periodically increasing the hot water temperature to $\geq 66^{\circ} \mathrm{C}$ at the point of use can be useful in the control of the colonization [3]. Anyway, although this type of thermal disinfection can be regarded as an effective control method, it has been seen that the genus Legionella has shown adaptation to a wide range of temperatures. Laboratory studies, for example, have shown that it can survive for $80-120 \mathrm{~min}$ at $50^{\circ} \mathrm{C}$ and $2 \mathrm{~min}$ at $60^{\circ} \mathrm{C}$ [10]. In real settings, some species, including L. pneumophila, were found able to grow at temperatures above $50^{\circ} \mathrm{C}$, and to survive up to $63^{\circ} \mathrm{C}$ [11]. Moreover, in some circumstances the temperature range between $50-59^{\circ} \mathrm{C}$ has been identified as the optimal condition for facilitating the emergence of different Legionella species [12]. Adaptations, spontaneous mutations or horizontal gene transfer from thermophilic Legionella species could support this eventuality. In particular, high levels of horizontal gene transfer responsible for the acquisition of thermotolerance have been shown for members of the genus Legionella within species and at the genus level by inter- and intra-species genome [13]. Furthermore, recently no significant correlation between distal site Legionella positivity and hot water return line temperature has been found. In particular, also buildings with a hot water return temperature $>51.1^{\circ} \mathrm{C}$ have been found positive for the bacterium in distal sites [14] These findings imply not only that temperature should not be used alone to predict the presence or absence of Legionella in a drinking water distribution system, but also that it is crucial to evaluate the effectiveness of the applied thermal water management program.

\subsection{Protozoa and Biofilm}

Thermal conditions also influence the relationship between Legionella and protozoa. Legionella can enter free-living amoebas by phagocytosis and is generally killed in lysosomes, where an acidic $\mathrm{pH}$ and lysosomal enzymes digest the bacteria. However, Legionella has evolved temperature-dependent strategies to prevent lysosome-mediated destruction and persist in a vacuole within the protozoan hosts. In particular, at temperatures $>25^{\circ} \mathrm{C}$, L. pneumophila replicates into amoebas and is released in the water while the protozoan host is killed. While at temperatures below $20^{\circ} \mathrm{C}$, amoebas infected by L. pneumophila eliminate the bacterium to the extracellular environment through a process of encystation [15].

Obviously, the need to avoid protozoan colonization of a water system is important not only to prevent the transmission of protozoa themselves [16] but also to decrease the risk of legionellosis because legionellae inside the protozoan cysts are protected against many harsh conditions. Thus, one of the key issues for controlling the growth of legionellae within protozoa is to recommend an effective disinfection method. However, there are several reasons why it is difficult to kill legionellae associated with protozoa.

When exposed to high temperatures or to chemicals, or in the absence of nutrients or oxygen, free-living protozoa transform to the cyst form to survive. It has been observed that the cysts can remain viable for more than 20 years under dry conditions [17] and 24 years at $4{ }^{\circ} \mathrm{C}$ in water [18], because they are metabolically inactive. The minimal temperature to kill the cysts is $65^{\circ} \mathrm{C}$ for most Acanthamoeba sp. isolates [19], but the cysts of some thermotolerant isolates could resist exposure at $80{ }^{\circ} \mathrm{C}$ for $10 \mathrm{~min}$ [20]. Amoebal cysts have also shown to be highly resistant to some high-level disinfectants such as biguanides, quaternary ammonium compounds, chlorine, and hydrogen peroxide, as well as to UV, $\mathrm{X}$-ray, and gamma irradiation [21]. 
Also, biofilm plays an important role in providing favorable conditions in which Legionella can grow because it provides protection from environmental stresses or disinfectants, access to higher levels of nutrients, and opportunities for symbiotic interactions with other microbes or protozoa. Interestingly, Klebsiella pneumoniae, Flavobacterium sp., Empedobacter breve, Pseudomonas putida, and Pseudomonas fluorescens are able to enhance the long-term persistence of L. pneumophila in biofilms [22-25] through the synthesis of capsular and extracellular matrix materials, which support the adherence [26-28], or because they provide growth factors for the bacterium [25]. On the contrary, other bacterial species such as Pseudomonas aeruginosa, Aeromonas hydrophila, Burkholderia cepacia, Acidovorax sp., and Sphingomonas sp. [25,29] antagonize the presence of L. pneumophila within the biofilm through the production of homoserine lactone quorum sensing (QS) molecules [30], or the production of bacteriocins [29]. It has been demonstrated that legionellae inside the biofilm matrix express phenotypes that differ from those of their planktonic counterparts and display an increased resistance to biocide treatments [31,32]. Thus, disinfectant type as well as substratum play an important role in the survival of L. pneumophila in biofilm within drinking water systems.

\subsection{Organic and Inorganic Sediment Accumulation}

Organic and inorganic compounds in water usually enhance Legionella premise plumbing colonization in the presence of ideal environmental factors, such as water temperature or $\mathrm{pH}$, low water pressure or stagnation, loss of disinfectant, or discontinuous disinfection.

Limiting the levels of assimilable organic carbon (AOC) in distributed water could reduce the risk of bacterial re-growth [33], but for controlling Legionella it should be associated with other operational approaches [34]. In fact, proposed limits for AOC are related to the presence or not of a water treatment, ranging from $10 \mu \mathrm{gL}^{-1}$ [35] to $32 \mu \mathrm{gL}^{-1}$ [36] in non-disinfected water, and $100 \mu \mathrm{gL}^{-1}$ in disinfected water [37]. Finally, small amounts of inorganic nutrients such as iron, zinc, and potassium also enhance the growth of L. pneumophila $[38,39]$.

\section{Disinfection Strategies}

\subsection{Oxidizing Agents}

Chlorine is widely used for its strong oxidizing power for primary disinfection treatment of potable water. It reacts with a variety of bacterial cellular components [40] and is able to permeabilize the cytoplasmic membranes causing leakage of proteins and DNA damage [41]. In order to inactivate microbial contaminants or to prevent a possible microbial regrowth in water distribution systems, the World Health Organization (WHO) recommends $0.5 \mathrm{mgL}^{-1}$ for free chlorine [42].

L. pneumophila has shown resistance to high levels of chlorine by the formation of biofilms [43], and pipes corrosion can be expected when the disinfectant is dosed in a water distribution system. In particular, high levels of residual chlorine are responsible for copper and iron pipes corrosion, while lead may not experience increased corrosion [44,45]. Maintaining the $\mathrm{pH}$ of the chlorinated water above 8 may counteract the corrosive effect of chlorine on copper and iron. Blends of poly- and orthophosphates can be used as corrosion inhibitors in order to create a passivating film on the pipe wall. However, the use of polyphosphates for corrosion control entails considerable uncertainty and risk because they may increase the leaching of pipe metal into the water [46].

Finally, the formation of potentially toxic and carcinogenic disinfection by-products (DBPs) has been identified in chlorinated drinking waters. The trihalomethanes (THMs) are likely to be the main chlorine DBPs. Because they usually occur together, total THMs are considered as a group, with an allowable concentration in drinking water ranging from $80 \mu \mathrm{gL}^{-1}$ [47] to $100 \mu \mathrm{gL}^{-1}$ [48]. THMs are formed by the interaction of aqueous-free chlorine with soluble, natural organic compounds present in water and their concentrations tend to increase with the presence of bromide or iodide, as well as with the increase of temperature, $\mathrm{pH}$, and chlorine dosage [49]. Removal of THMs or their precursors is 
difficult and involves resource-intensive processes [50] like for example ozonation and biological granular activated carbon [51] or magnetic graphene oxide [52]. Nevertheless, the technologies described above could be time-consuming and extremely expensive. For this reason, an effective method to control DBPs in drinking water may be the use of alternative disinfectants.

Chlorine dioxide is a water-soluble gas that can easily diffuse through bacterial cell membranes. When compared to chlorine, chlorine dioxide has been found to be superior in penetrating biofilms [32] and in inactivating free-living protozoa such as Acanthamoeba strains [53].

It has been demonstrated that using chlorine dioxide as secondary disinfectant can significantly reduce the risk of acquiring Legionnaires' disease in hospital settings [54-56]. A total chlorine dioxide residual of $0.1-0.5 \mathrm{mgL}^{-1}$ at the tap is usually sufficient to control Legionella colonization, but higher residuals may be necessary in heavily colonized water systems [9].

Chlorine dioxide is less corrosive than chlorine [32]. Nevertheless, there is evidence that it can cause damage to polyethylene pipes $[57,58]$. Finally, although it does not form appreciable amounts of THMs and halo acetic acids (HAAs), it has been seen that onsite generation of chlorine dioxide often involves the production of free chlorine, which tend to increase with reaction time. Therefore, the ratio of chlorine dioxide to chlorine needs to be constantly monitored and possibly adjusted to obtain the best control of DBPs formation [59].

Monochloramine is formed by the reaction of ammonia with chlorine. For primary disinfection of drinking water, the target concentration for the disinfectant is $1.5-3.0 \mathrm{mgL}^{-1}$ as $\mathrm{Cl}_{2}$ but the optimal concentrations may depend on the manufacturer. The WHO recommends $3 \mathrm{mgL}^{-1}$ [60] while the Environmental Protection Agency (EPA) concentration is $4.0 \mathrm{mgL}^{-1}$ as $\mathrm{Cl}_{2}$ [61]. However, monochloramine is often used as a secondary disinfectant after primary treatment with chlorine, especially in distribution systems heavily colonized by Legionella [62].

Monochloramine seems to react slowly with nucleic acids but rapidly with several amino acids, with little damage to bacterial membranes [63]. This could explain why measurements of free chlorine and monochloramine biofilm penetration show that monochloramine is more effective at penetrating biofilms than is free chlorine, although increased penetration does not correlate with greater inactivation of biofilm microorganisms. However, monochloramine has shown to be more effective on copper biofilms while free chlorine is more effective on polyvinyl chloride drinking water biofilms [64]. Finally, the lower reactivity of monochloramine can also be an advantage, as it is less likely to react with natural organic matter in the water, forming fewer DBPs, and leading to fewer undesirable tastes and odors than chlorine or chlorine dioxide [65].

The main disadvantage of monochlorination of the water is the nitrification by nitrifying bacteria of ammonia or free ammonia released by the decay of the disinfectant. Nitrification results in the formation of toxic nitrite in the distribution system. Moreover, the nitrification process has the potential to locally lower the $\mathrm{pH}$ in alkaline waters and cause corrosion of elastomeric materials. Factors influencing nitrification include the rate at which monochloramine residual decays, microbial regrowth, corrosion of pipe materials, as well as biofilm formation. Biofilm, in particular, facilitates the growth of nitrifying bacteria, promoting nitrification in water systems [66,67]. One way to potentially control nitrification in premise plumbing systems is through the development of specific building management plans. Optimizing the chlorine-to-ammonia ratio, typically 5:1 [68], flushing out the outlets [69], decreasing monochloramine residence time in service reservoirs [70], chlorite addition [71], reducing natural organic matter and preventing biofilm formation [34,72,73], as well as controlling the $\mathrm{pH}[74,75]$ may be effective methods of controlling and preventing nitrite formation.

Ozone is considered the most efficient disinfectant for all types of microorganisms because it is able to oxidize the cell membrane and wall constituents of a bacterial cell, as 
well as enzymes and nucleic acids. Under experimental conditions, it has demonstrated to be more effective at inactivating L. pneumophila than other disinfectants [76,77]. Nonetheless, determination of the in vitro activity of ozone against the bacterium does not predict the efficacy of its eradication from water fixtures [78]. In fact, studies in real water systems show no significant reduction in Legionella colonization $[79,80]$.

Its low effectiveness against Legionella is probably due to the fact that ozone does not stay in water sufficiently long to provide a residual effect. For this reason, chlorine can be added after ozonation, but DBPs may be produced by their combinations. In fact, the vast majority of the ozone DBPs identified up to now contain oxygen in their structures, with no halogenated DBPs observed except when chlorine or chloramines are applied as a secondary disinfectant [81]. Moreover, there is evidence that the use of ozone as a primary disinfectant may cause a shift to more brominated DBPs during subsequent chlorination [82].

Hydrogen peroxide is a strong oxidizing agent that oxidizes microorganisms' enzymatic systems, releasing free oxygen atoms without the formation of DBPs. The European directive established a concentration limit for hydrogen peroxide in drinking water of $25 \mathrm{mgL}^{-1}$ [83]. While the US Environmental Protection Agency [84] guidelines recommend 25-50 ppm of residual hydrogen peroxide in drinking water. Concentrations of $25 \mathrm{mgL}^{-1}$ have demonstrated good efficacy in controlling Legionella colonization of water networks, with a higher disinfection power with the increase of the water temperature up to $40-50^{\circ} \mathrm{C}[85,86]$. Finally, to enhance its activity, hydrogen peroxide is sometimes used in combination with other oxidants such as ozone, silver, or UV irradiation.

\subsection{Non-Oxidizing Agents}

Copper-silver ionization is commonly used in water distribution systems with hot water recirculating loops [32]. When used together, copper and silver ions create a synergistic effect. In fact, the copper ions destroy the cell wall permeability, which allows the silver ions to interfere with the synthesis of proteins and enzymes, thus resulting in a higher inactivation rate of L. pneumophila [87]. For Legionella control, the recommended copper and silver ion concentrations are $0.2-0.4 \mathrm{mgL}^{-1}$ and $0.02-0.04 \mathrm{mgL}^{-1}$, respectively [32].

Literature data show that there are at least three major challenges facing copper-silver ionization [88-90]: (i) ensuring that the added ions are flushed throughout the entire water distribution system, ( $i$ ) the emergence of resistant legionellae, and (iii) the reduction in the microbiocidal power due to the formation of metal complexes. Finally, copper-silver ionization may increase chlorine DBPs formation at $\mathrm{pH} 8.6$ in the presence of natural organic matter [91].

Short-wavelength UV is believed to have biocidal effects through a molecular rearrangement of the purine and pyrimidine components of the nucleoproteins, which hampers DNA replication [92]. Breaks in the bonding structure also occur [93]. Nevertheless, the current technology of low-pressure (LP) mercury lamps that is used for UV irradiation has several shortcomings.

First of all, Legionella is able to repair damages to DNA [94]. Secondly, the maximum absorbance of nucleic acids is around $260 \mathrm{~nm}$, while proteins have a relative maximum absorbance of around $280 \mathrm{~nm}$ [95]. Thus, targeting one of the components of the bacterial cell may be more effective in Legionella inactivation [96]. LP mercury lamps emit at $254 \mathrm{~nm}$, and this may result in a low efficacy of inactivation. On the contrary, the irradiation technology using light emitting diodes (LEDs) can emit at many different wavelengths in the UV-B and UV-C. Moreover, LP lamps contain mercury, which is toxic to the environment, while LEDs are made of gallium/aluminum nitride or aluminum nitride, which are not toxic nor hazardous.

Regardless its technology, UV light produces no residual. Therefore, if a residual is desired, another disinfectant must be used. To this regard, the application of UV light to shower heads and faucets in hospitals has indicated that the technology alone is insufficient to control Legionella, and other disinfection measures have to be used along with UV 
irradiation for an effective control of the colonization [92]. Finally, UV light shows poor penetration in biofilms [97].

\subsection{Point-of-Use (POU) Filtration}

Disinfectants may not reach dead legs or low water flow areas. Furthermore, they can dissipate through the plumbing system, making them less effective at distal points, and secondary chemical water disinfection may shorten the life of the pipes. For these reasons, point-of-use (POU) filtration can be regarded as an additional barrier to add to other primary treatment technologies to prevent exposure to legionellae, particularly in hospital settings. The filters are attached to individual faucets and showers, providing a physical barrier between Legionella and high-risk patients. Anyway, a recommendation for their use cannot be made until an evaluation of their efficacy has been performed [98].

It has been seen, for example, that the application of carbon filters may result in a greater presence of Legionella in water because the bacterium can colonize the filters while passing through $[99,100]$. On the contrary, membrane filters have shown to control the colonization of hospital water systems up to 2-8 weeks of continuous use [101,102], especially when they are covered with a silver layer [103]. More recently, the novel electrically heatable carbon nanotube (CNT) point-of-use (POU) filters have demonstrated to remove $99.9 \%$ of L. pneumophila in water [104].

Obviously, one filter is needed for each fixture, and if the filters are not regularly replaced, Legionella can colonize them regardless of their technology. Therefore, replacing these filters may be expensive. For this reason, the use of filters, which requires fewer change-outs, could be a cost-effective method for preventing hospital-acquired Legionnaires' disease [105].

\section{Emerging Treatment Technologies}

As discussed above, chemicals dosed into the water systems could have a negative impact on the environment and human safety. For these reasons, alternative disinfection strategies are needed. Literature reports some alternative treatment technologies against legionellae that are, mostly, based on natural biocide molecules, or structural and/or chemical modification of materials to be used as repellant surfaces for water pipes and filters.

\subsection{Essential Oils (Eos)}

Essential oils (Eos) are aromatic oily liquids obtained from plant material (e.g., flowers, seeds, leaves, or roots). They are mainly composed of a mixture of terpenoids and aromatic compounds, which have shown an antibacterial activity. Although EOs antibacterial activity could not be linked to one specific mechanism, scanning electron microscopy analysis has shown morphological alterations of L. pneumophila when treated with Thymus vulgaris EO, suggesting a loss of cytoplasmic membrane integrity [106].

EOs extracted from Cinnamomum osmophloeum leaves, in particular, have demonstrated a strong activity against L. pneumophila at $42{ }^{\circ} \mathrm{C}$ in cooling towers [107] and at $\mathrm{pH} 8-10$ in recreational spring waters [108]. Lemon, peppermint, sage, and thyme oils have also shown to have a good anti-biofilm activity [109]. Finally, Melaleuca alternifolia Cheel (tea tree) oil (TTO) has demonstrated to be active as anti-Legionella disinfectant for control contamination especially in spas, in small water distribution systems or in respiratory medical devices [110].

\subsection{Biosurfactants}

Biosurfactants are a group of natural biocide molecules produced by bacteria, yeasts or fungi, which seem to act by direct lysis of negatively charged membranes [111]. So far, only few studies have reported the anti-Legionella activity of biosurfactants produced by Pseudomonas strains [112], and various Bacillus environmental isolates [113]. Surfactins produced by Bacillus subtilis, in particular, were found to breakdown L. pneumophila preformed biofilms, but they did not prevent biofilm attachment [114]. Finally, cell-free 
supernatants produced by Lactobacillus rhamnosus and Lactobacillus salivarius showed high antibacterial activity against L. pneumophila strains isolated from hot tap water [115].

\subsection{Smart Surfaces}

Smart surfaces are an emerging material technology able to respond dynamically to changes in the environment via the incorporation of stimuli-responsive polymers (SRPs) into the material surface. Various stimuli may be used to trigger antibacterial action [116]. A smart surface composed by nanostructured silicon nanowires has been recently proposed. Once chemically modified with (3-aminopropyl)triethoxysilane and chlorhexidine digluconate, these nanowires seem to provide an efficient decrease of planktonic and surface-attached microorganisms, thus reducing their subsequent survival and the possibility of adaptive process [117].

A sulfonated pentablock copolymer (s-PBC, commercially named Nexar ${ }^{\mathrm{TM}}$ ) has demonstrated to induce the death of $P$. aeruginosa by a contact killing mechanism in which the polymer acidifies the water close to its surface, causing the microbial replication inhibition [118]. According to the reported previous work, the same authors performed a preliminary experiment using $L$. pneumophila sg 2-14 instead of $P$. aeruginosa. A modified Zone of Inhibition test using polypropylene (PP) coupons that have been deposited with the s-PBC (s-PBC@PP) was used to test its bactericidal activity. In this case, $0.2 \mathrm{~mL}$ of water were spotted below a s-PBC@PP and a reference PP coupon in a Glycine Vancomycin Polymyxin Cycloheximide (GVPC) Legionella agar selective medium inoculated with the target bacteria. As reported in Figure 2, after $24 \mathrm{~h}$ a clear zone of $2 \mathrm{~cm}$ diameter appeared all around the s-PBC@PP coupon (A), while microbial colonies were still visible nearby the $\mathrm{PP}$ coupon (B), proving that the s-PBC, acidifying the water volume, was able to induce the death of those legionellae that were directly exposed to the modified surface. The results of this first test are promising, and further investigations are in progress.

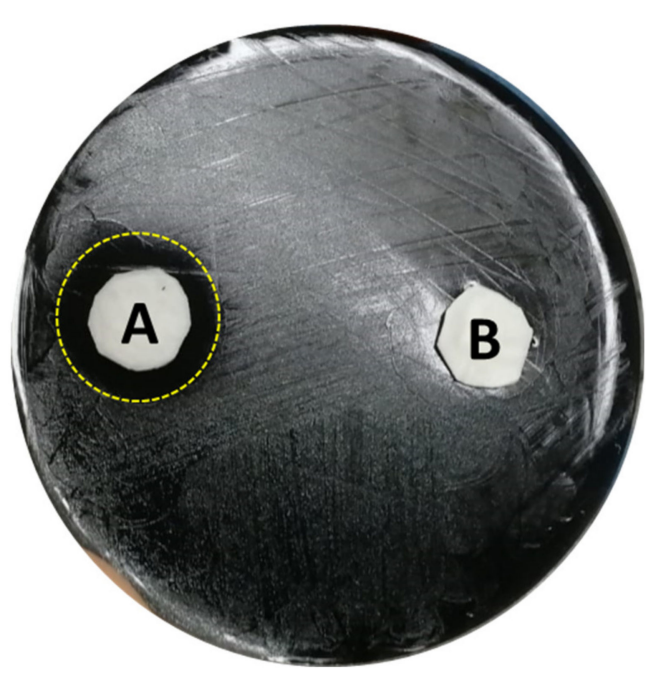

Figure 2. Modified Zone of Inhibition Test of Legionella pneumophila 2-14 after $24 \mathrm{~h}$ incubation with s-PBC@PP (A) and reference PP (B) coupons after $0.2 \mathrm{~mL}$ spotting of water. The yellow dot ring evidences the $2 \mathrm{~cm} \varnothing$ clear zone.

\section{Water Sampling}

As underlined by many guidelines and technical reports, one of the main objectives of water sampling for environmental surveillance is confirmation or exclusion of a water system as a source of infection. Routine environmental sampling could also be useful for distinguishing between local or system-wide colonization of the water system, as well as for identifying critical sites and selecting the appropriate strategy for short- and long-term control of Legionella. 
The number and types of sampling sites must be determined on the water system basis because of the diversity of the environmental conditions, namely water physical and chemical characteristics, plumbing materials, heating, disinfection method, etc. Key components of water sampling also include site selection and sampling frequency, sample type (i.e., biofilm, water, etc.), as well as flow patterns (e.g., first-flush, post flush).

For a full system perspective, water samples should always be taken from water mains, water softeners, holding tanks, water heaters (inflows and outflows), faucets, and shower heads at the proximal and distal end of the water system and at a number of representative points in between. Selection of sampling sites depends on whether the sampling is for routine monitoring or to investigate an outbreak.

For routine monitoring, sampling points are chosen taking into consideration the sectors of the building more at risk of Legionella proliferation (e.g., dead-ends or areas with infrequent use, etc.). Furthermore, monitoring the temperature of cold and/or hot water systems (e.g., the hottest and the coldest point, respectively) could be a useful approach for identifying points that are susceptible to Legionella colonization [119].

In the case of outbreaks, sampling plans are useful to identify all potential sources of contamination. For cold water, the main sampling points are the incoming supply, the outlet of each reservoir, as well as outlets closest to the reservoir. Sampling of hot water systems should include showers and taps used by infected people or in proximal areas. Finally, evaporative cooling systems, spa pools, humidifiers and decorative fountains should be considered as possible sources of infected aerosols. [120].

Researches on environmental monitoring show that testing water regularly for the presence of Legionella may also be a guide to verify the efficacy of disinfection. The WHO, in particular, recommends drinking water cultures for Legionella every 3 months [121].

In Sicily (Italy), surveys of hospitalized and non-hospitalized (marine, touristic and corporate) facilities in the central-eastern part of the region revealed $\sim 46 \%$ and $30 \%$ of hot water systems highly colonized by Legionella, respectively, as reported in Table 1. L. pneumophila 2-16 was the most frequently isolated serogroup [62,122-126]. For each facility, a first preliminary inspection of the water system conditions focusing on cleanliness, water turbidity, wall slime, sludge, general repair, access, and location of the sampling points was carried out. Furthermore, technical information regarding the plumbing systems (e.g., pipe materials), water treatment (e.g., type and concentration of the disinfectant, continuous or discontinuous disinfection), previous notification of cases of legionellosis etc., were collected. In hot water systems, the following sampling points were always considered: water heaters set at low temperatures $\left(<50{ }^{\circ} \mathrm{C}\right)$, water tanks, water softeners, taps, and faucets (pre-flush, post-flush).

Table 1. Legionella screening in water systems of central eastern Sicily facilities.

\begin{tabular}{cccc}
\hline Type of Facility & Total Samples & Positives (\%) & SG 2-16 (\%) \\
\hline Hospitals & 2610 & $1193(45.7)$ & $823(69)$ \\
Marine & 1133 & $246(21.7)$ & $184(74.8)$ \\
Touristic & 582 & $146(25.2)$ & $83(56.8)$ \\
Corporate & 196 & $69(35.2)$ & $61(88.4)$ \\
\hline
\end{tabular}

The role of routine testing of water systems for the monitoring of Legionella has been subjected to some scientific debate. Sometimes it has been shown the lack of correlation between water sampling results and human health risk [127,128]. This may be due to the fact that each sampling event might not capture the true dynamics of Legionella within a water system. In fact, a study examining 84 taps over 5 consecutive days in an Italian hospital revealed significant variation of the Legionella load from day to day, although the pattern was similar across the wards monitored [129]. Additionally, it has been shown that high percentages of legionellae in water systems are not culturable. 


\section{Viable but Non Culturable (VBNC) State}

Legionellae are able to persist in adverse environmental conditions as vegetative cells with low metabolic activity, via the activation of the viable but non culturable (VBNC) state. VBNC cells are viable cells that have lost their ability to grow on routine culture media but they generally maintain their ability to cause infection $[130,131]$. It has been recently demonstrated that VBNC legionellae can directly infect human macrophages and amoebae even after 1 year of starvation in ultrapure water. Thus, amoeba infection by starved VBNC strains, which usually occur in biofilms, will result in an increase of legionellae in water systems [132]. The real number of metabolically active legionellae will be, in turn, underestimated by the use of conventional culture techniques.

It has been seen that under stressful conditions (e.g., chemical disinfectants, UV light, heat, etc.), two different types of VBNC legionellae can be produced [131]: (i) the damaged VBNC type, in which the cells are on the way to death and thus they have lost their ability to infect humans; (ii) the injured VBNC type, in which legionellae retain their pathogenicity because they undergo a physiological adaptation to stress through a change in the gene expression and may resuscitate when the stress is removed. Therefore, it is of paramount importance to apply the most reliable detection method able to differentiate between culturable and VBNC cells.

\subsection{VBNC-Legionella Isolation Methods}

The gold standard method for Legionella detection is the routine culture technique, consisting in water filtering and plate counts of visible colonies [133]. However, direct colonies observation is not the best solution for the VBNCs identification and quantification, since it tends to overlook those cells that are viable, potentially proliferating and virulent, but non-culturable [134]. In this sense, many efforts have been made in order to improve the performances of culturing methods. Some attempts, for example, were based on the integration of cytometry to reduce the time consumption. Other trials were based on the addition of a preliminary immune-separation step to increase the yield by identifying the total number of viable cells (including the not culturable) $[135,136]$. Some efforts were, instead, focused on the resuscitation of VBNCs by co-culture with amoebae to make Legionella cells again culturable and restoring their colony formation and identification, but implied a long procedure resulting in being unsuitable for the routine analysis of VBNCs [137].

To solve the ambiguity issue in the VBNC detection, other approaches focus on the VBNCs identification and counts via the bacteria membrane staining. These methods are based on the analysis of membrane integrity (in terms of protection, nutrients transport, oxidative phosphorylation, etc.) by labelling bacteria with specific hydrophilic dyes such as the propidium iodide. In this way, the intact phospholipidic bilayer of live cells blocks the dye penetration, while dead cells with damaged membranes allow the chromophore to pass and bind the DNA, giving a red-orange fluorescence after excitation with a $488 \mathrm{~nm}$ light [138]. Many kits (e.g., BacLight kit from Thermo Fisher) use this kind of dye in combination with others able to penetrate the healthy bacterial cells, giving a dualistic fluorescent response [139]. However, these kits have the main limitation of live cells number overestimation, since not all the dead cells have their cell membrane totally and/or always compromised.

Another cell parameter used to evaluate the cell viability and the VBNC number is the membrane potential. Some evidences report methods based on fluorescent probes that can pass only those membranes having a zero potential to stain only those cells that are in starvation condition (i.e., the VBNCs) [140]. Other membrane potential based methods report the use of cationic probes (e.g., potassium ions) that, after a prolonged exposure to measured bacteria, are spectroscopically quantified inside cells in order to test the decrease of the transmembrane transport activity [141]. This feature was also evaluated analysing the uptake of redox- or radioactive probes by electrochemical or micro-autoradiography analysis [142]. Sometimes, instead, the membrane potential analysis is combined with flow 
cytometry to measure the change of light scattering given by the size decrease of VBNC cells, allowing their quantification by count of the dimensional variants. However, for most of the proposed approaches, there is a high percentage of positive signals that can be obtained with viable and culturable cells [143], which makes the membrane potential-based methods not totally exhaustive for an accurate VBNCs detection and quantification.

The metabolic analysis of Legionella solves some of the previous issues and drawbacks, focusing on the functional characterization of enzymes that are essential for the bacteria physiology preservation, such as esterase, arylamidase, phosphatase, phosphohydrolase, and glucosidase [144]. The esterase activity, for example, can be tested by using specific substrates that act as membrane permeant fluorescent dyes. These molecules reveal their fluorescence only if esterase is active, since the enzyme cleaves the substrate giving a fluorescent derivate (and a specific light emission), and if the membrane is totally intact, allowing the fluorescent product to be retained and accumulated [145].

The fluorescence in situ hybridization (or FISH) is, also, reported to be a valid technique for the VBNC detection. Based on the direct intracellular hybridization of labelled oligonucleotide probes, as the 16S rRNA [146], this approach provides a viability assay through the bacteria transcriptome analysis, revealing the expression of vital genes. However, it is often affected by weak probes fluorescence signals and/or low detection specificity, caused by the cross-reactivity towards other Legionella species [145]. Some evidences, however, reported improved FISH approaches as the combined Direct Viable Count-FISH (DVC-FISH), a rapid and specific tool to identify pathogenic Legionella spp. and L. penumophila viable cells harboured by amebae in water sources [147], and the Catalysed Reporter Deposition-FISH (CARD-FISH), an enhanced FISH to detect cells transcriptome with low ribosome content [145], which excludes the risk of cross-reactivity. However, some scenarios, such as those caused by the heat or chemical treatment, report intact rRNA molecules inside cells that have compromised their membranes, so that the rRNA analysis by FISH itself results to be not totally reliable as a proof of Legionella viability.

Molecular techniques, mostly based on the quantitative real-time PCR (qPCR), are valid alternative approaches able to guarantee a rapid, sensitive, and specific detection of Legionella and its VBNC [148]. Conventional qPCR methods, like for example those based on the use of $16 \mathrm{~S}$ rRNA as viability indicator [149], can perform an accurate detection of Legionella in a few hours although they are limited by a DNA persistence in dead cells, which causes an overestimation of viable cells and a risk to collect false-positive results [150]. Thus, new PCR approaches combining the amplification reaction to some permeant nucleic-acid-binding dyes have been introduced. These viability PCR (v-PCR) methods provide an exhaustive discrimination between live and dead cells thanks to dyes such as the propidium monoazide (PMA) and ethidium monoazide (EMA) that are able to penetrate only damaged membranes of dead cells and bind covalently to the intracellular genome, thus blocking its subsequent amplification by PCR. In this way, the amplification occurs only for viable cells, reducing the risk of VBNCs discarding and dead cells overestimation, which is typical of conventional qPCR and culture methods [148,151]. Moreover, some evidences of combined v-PCR approaches, such as that including a preliminary immunomagnetic separation step before the PMA-PCR reaction to increase the level of cells purification [152], suggest the possibility to improve these amplification methods, providing sensitive, selective, simple, and rapid bacteria detections in water towards innovative environmental monitoring applications.

\subsection{Emerging Detection Methods}

Nowadays, many research efforts have been spent in the development of advanced biosensors for the viable bacteria revelation in water. Biosensors are versatile and customizable systems able to guarantee a biological analysis without the need for bulky instruments and complex protocols, thus reducing the lab constrain and time/cost consuming typical of consolidated methods. They basically work through a perfect synergy between the selective biological or biomimetic recognition element and the transducer (e.g., optical, 
electrical, electrochemical, etc.) operating the target revelation [153,154]. If opportunely implemented, biosensors can provide a fast revelation of bacteria together with a high degree of miniaturization and integration of the entire analytical system, ideal for in situ and remote-controlled applications. The antimicrobial peptide (AMP)-based biosensors, for example, introduced rapid, reliable, and cost-efficient tools for the direct recognition of floating bacteria in contaminated water [155]. The "watersampling" chip has shown to be able to reveal viable pathogens in water by the real-time electrical detection of their interactions with anchored AMP, reaching a Limit of detection (LoD) of 1 cell/ $\mu \mathrm{L}$ [156], which is promising towards the VBNCs detection.

Another example is represented by the silicon-based biosensors, which have brought an important breakthrough in the biological sensing thanks to the properties of the material used. Silicon, in fact, is a biocompatible substrate that allows to embed all the stuff required for the sensing process, from probes and reagents to the detection module, and is suitable for a wide series of further implementations, as dedicated staining techniques [157,158], microfluidics integration [159], detector downscaling (integrated microelectrodes, microsized photomultipliers, etc.) [160,161], and nanostructured-based functionalization [162]. This implementation is reported, for example, by authors who recently developed an optical system based on a nanostructured oxidized porous silicon (PSi) thin film exposing specific antibodies against Escherichia coli for its real-time detection in water. The system, reporting a LoD of $10^{3}$ cells $/ \mathrm{mL}$, works through an optical revelation of the bacteria-antibodies complex performed by directly measuring their light reflection through a charge-coupled device (CCD), an integrated circuit containing an array of linked or coupled capacitors [163]. Most of the biosensors described above have been validated only for few pathogens species such as E. coli and Salmonella [164] but considering the analytical approaches and performances reported, they could be reasonably applied to the VBNC-Legionella detection.

\section{Water Systems Management}

Water systems management programs are recommended to prevent Legionella growth in buildings with large or complex water systems, including health care facilities. Understanding the biological and environmental factors that contribute to the persistence and colonization of a water system can be detrimental to eradicate and prevent the transmission of Legionella.

As discussed above, although surveillance of water systems can be regarded as an important component of the primary prevention of legionellosis, especially in hospital settings, risk assessment based solely on counts of Legionella may be misleading and financially consuming $[127,128]$. Instead, information about the presence and the extent of the colonization of the water system should be spent on managing appropriate control measures within a Water Safety Plan (WSP) [165].

\section{Water Safety Plan (WSP)}

Water Safety Plans (WSPs) are drawn on the principles from other risk management strategies, such as the multiple-barrier approach and Hazard Analysis and Critical Control Points (HACCP). According to the indications of the WHO [165], a WSP is composed of four main steps.

The first step, "system assessment", provides a systematic assessment and prioritization of hazards and control measures related to the water system. The size and complexity (e.g., pipe materials, dead legs, water flow conditions, etc.) of the water system might increase the risk of Legionella colonization. Thus, a comprehensive understanding and description of the system is fundamental for the identification of the hazards and the assessment of the risks. For this reason, the first stage in developing a WSP is to form a multidisciplinary team of professionals with sufficient expertise in building management, as well as in distribution and treatment of drinking-water, such as engineers, water quality specialists, hygienist professionals, and operational staff. 
A semiquantitative matrix is typically used for identifying the likelihood of occurrence of a risk (rare, possible, certain) and evaluating the severity of consequences of the hazard (insignificant, major, catastrophic): a risk ranked above the "cut-off" point will require immediate attention. Risk ranking will also provide a starting point for prioritizing remediation actions and will help the decision-making process.

Preventing Legionella colonization of the distribution system will depend on the design and operation of the system, as well as on the most effective maintenance and survey procedures. For this reason, the second step, "monitoring", of a WSP focuses on the identification and evaluation of the applied control measures.

Typically, control measures are applied collectively to eliminate or significantly reduce the occurrence of an hazard. Identification and implementation of control measures require a multiple-barrier approach: a failure of one barrier may be compensated by the remaining barriers. For this reason, assessment of existing control measures is necessary in evaluating whether they are effective in reducing the risk to acceptable levels. Obviously, if improvement is required, alternative and additional control measures that could be applied should be evaluated.

As already discussed, Legionella grows better in water systems that are not adequately managed. In general, the principles of an effective water management include measures that prevent Legionella growth, such as assuring water temperatures outside the ideal range; avoiding water stagnation; scale and corrosion, which in turn promote biofilm growth; as well as ensuring an adequate disinfection method [166]. A number of control measures can be adopted to reduce the risk of Legionella colonization of a water system. Taking into consideration the multiple-barrier approach, by decreasing the contamination of the source water or reducing retention of water in storage tanks, for example, the amount of chemical treatment required is reduced. This may in turn reduce the production of disinfection by-products (DBPs) and minimize operational costs. Other barriers to contamination of the water system may be those related to water disinfection. Application of an adequate concentration of disinfectant is an essential element to reduce the risk. Anyway, hazards may be introduced during treatment. Thus, where chemical disinfection is used, for example, measures to minimize DBPs formation should be taken into consideration. In this case, storage of water after disinfection and before supply to consumers could reduce chemicals' demand and improve remediation by increasing disinfectant contact times. Control measures may also include using a more stable secondary disinfectant (e.g., monochloramine instead of chlorine). This can be particularly important when Legionella is associated with protozoa and/or biofilm and to prevent corrosion of pipe materials and the formation of deposits. Furthermore, storage tanks and reservoirs should be securely roofed and equipped with an external drainage to prevent Legionella contamination and to avoid water stagnation, respectively. Flushing and maintaining positive pressure throughout the entire water system could also be an effective control strategy to avoid stagnation. In fact, in systems where there are dead-legs or water is supplied intermittently, the risk of colonization is very high. Obviously, where household storage is used to overcome intermittent supply, localized use of disinfectants to reduce microbial proliferation may be necessary.

The third step, "management and communication", describes actions to be taken during normal operation and in case of incidents and emergency situations (e.g., remedial actions after adverse monitoring results, notification of a case of legionellosis, etc.). This step underlines the need of proactive water management plans.

The management plan will include both responses to normal variations of monitoring parameters and responses when operational monitoring parameters reach or overcome critical limits. During an emergency, for example, actions may include restricting access to water or temporarily use an alternative water source, if possible. It may be necessary to increase the level of disinfectant or to additionally disinfect the water. In addition to the periodic review, it is important that the WSP is reviewed following every incident 
or unforeseen event in order to identify areas for improvement, revise risk for the risk assessment, or identify new risks, focusing on and acting against the cause of the incident.

Communication and collaboration among environmental and Public Health experts is also imperative. Communication strategies should include procedures for promptly advising any significant incidents within the water system, including notification of the public health authority.

The fourth step, "surveillance", provides an indication of the overall performance of the WSP through the systematic collection of data (e.g., periodically sampling for legionellae in water, verifying the disinfectant level or water temperature) to verify if control measures applied are operating properly.

Although WSPs require a certain minimum number of steps involved, it should be regarded as a flexible approach that should build on and improve existing practice. Starting with existing treatments to ensure that they are operating at their optimum is one of the main key components of WSPs implementation, because this is often the principle barrier that prevents Legionella from colonizing the water distribution system. On the other hand, for reducing Legionella risks in new buildings, water systems should be designed to ensure and facilitate safe system operation and maintenance. For example, water systems should be designed to prevent microbial growth, minimize corrosion, and maintain internal surfaces in a clean condition. This designing should be regarded as an integral component of an effective risk control strategy. In particular, the following requirements for water systems should be assessed in the planning stages: avoiding water storage tanks supplying calorifiers; using point-of-use water heaters rather than centralized hot water systems; minimizing the distance between the source of the water supply and point of use; designing distribution systems to ensure regular circulation of water by eliminating dead legs; insulation of the pipes to minimize the transfer of heat between hot and cold water distribution pipework; installing thermostatic mixing valves (TMVs), when used, as close as possible to the point of use. Finally, as already discussed, legionellae are usually associated with biofilms in water systems. Thus, consideration should be given to the materials used in the construction of water distribution systems. Copper seems to be the best at limiting biofilm formation, followed by polybutylene and stainless steel, whereas polyethylene, chlorinated polyvinyl chloride (PVCc), unplasticised polyvinyl chloride $(\mathrm{PVCu})$, steel, and ethylene-propylene encourage biofilm formation.

\section{Conclusions}

Growth of Legionella in water systems poses an increasing Public Health concern. Temperature, water quality, $\mathrm{pH}$ fluctuations, scale, changes in water pressure, stagnant water, pipe materials, as well as inadequate levels of disinfectant can influence the colonization and growth rate of Legionella. Biofilm also plays an important role in providing favorable conditions in which Legionella can grow by providing protection from the effects of biocides.

A preventive proactive approach should be based on specific water management programs, which might comprise the identification and assessment of the risk, the implementation of a WSP, and the application of the most appropriate disinfection treatment.

Routine water samplings to detect Legionella is necessary to assess the risk because the level of colonization may vary over time. Water samplings could be useful in monitoring the effectiveness of the control measures applied. However, the implementation of a risk assessment plan to predict the risk of legionellosis based solely on culture-based enumeration in a water system contains many uncertainties. Evaluation of factors that may indicate increased risk, such as population risk factors and/or presence of water system's elements associated with an increased risk, could be more useful in establishing engineering control strategies. The Public Health departments might serve as a resource to building managers during the development, implementation, and evaluation of the water system management.

Author Contributions: Conceptualization, M.A.C. and E.L.S.; investigation, E.L.S., S.F., S.S., S.L., D.C., G.F. and M.A.C.; data curation, E.L.S., P.L., M.A.C.; writing-original draft preparation, E.L.S. 
and M.A.C.; writing-review and editing, P.L., S.F., S.S., S.L. and M.A.C.; supervision, M.A.C. All authors have read and agreed to the published version of the manuscript.

Funding: This research received no external funding.

Conflicts of Interest: The authors declare no conflict of interest.

\section{References}

1. Centers for Disease Control and Prevention. Legionnaires' Disease associated with potting soil-California, Oregon, and Washington, May-June 2000. MMWR Morb. Mortal. Wkly Rep. 2000, 49, 777-778.

2. Katz, S.M.; Hammel, J.M. The effect of drying, heat, and pH on the survival of Legionella pneumophila. Ann. Clin. Lab. Sci. 1987, 17, 150-156.

3. Sehulster, L.; Chinn, R.Y.W.; Centers for Disease Control and Prevention. Guidelines for environmental infection control in health-care facilities: Recommendations of CDC and the Healthcare Infection Control Practices Advisory Committee. MMWR Morb. Mortal. Wkly Rep. 2003, 52, 1-42.

4. European Technical Guidelines for the Prevention, Control and Investigation, of Infections Caused by Legionella Species. ECDC. 2017. Available online: https://ecdc.europa.eu/sites/portal/files/documents/Legionella\%20GuidelinesFinal\%20updated\%20 for\%20ECDC\%20corrections.pdf (accessed on 9 February 2021).

5. Ministero Della Salute. Linee Guida per la Prevenzione ed il Controllo Della Legionellosi. 2015. Available online: http: / / www.salute.gov.it/portale/documentazione/p6_2_2_1.jsp?id=2362 (accessed on 9 February 2021).

6. Sathasivan, A.; Chiang, J.; Nolan, P. Temperature dependence of chemical and microbiological chloramine decay in bulk waters of distribution system. Water Sci. Technol. Water Supply 2009, 9, 493-499. [CrossRef]

7. García-Ávila, F.; Sánchez-Alvarracín, C.; Cadme-Galabay, M.; Conchado-Martínez, J.; García-Mera, G.; Zhindón-Arévalo, C. Relationship between chlorine decay and temperature in the drinking water. MethodsX 2020, 7, 101002. [CrossRef]

8. Pan, J.; Rhoads, W.J.; Edwards, M.A.; Pruden, A. Effect of heat shock on hot water plumbing microbiota and Legionella pneumophila control. Microbiome 2018, 6, 30.

9. Health and Safe Executive (HSE). Legionnaires' Disease. Part 2: The Control of Legionella Bacteria in Hot and Cold Water Systems. 2014. Available online: www.hse.gov.uk/pubns/priced/hsg274part2.pdf (accessed on 9 February 2021).

10. Erdoğan, H. Legionnaires' Disease. Mediterr. J. Infect. Microb. Antimicrob. 2018, 7, 2. [CrossRef]

11. Lesnik, R.; Brettar, I.; Höfle, M.G. Legionella species diversity and dynamics from surface reservoir to tap water: From cold adaptation to thermophily. ISME J. 2016, 10, 1064-1080. [CrossRef]

12. Dilger, T.; Melzl, H.; Gessner, A. Legionella contamination in warm water systems: A species-level survey. Int. J. Hyg. Environ. Health 2018, 221, 199-210. [CrossRef]

13. Gomez-Valero, L.; Rusniok, C.; Jarraud, S.; Vacherie, B.; Rouy, Z.; Barbe, V.; Medigue, C.; Etienne, J.; Buchrieser, C. Extensive recombination events and horizontal gene transfer shaped the Legionella pneumophila genomes. BMC Genom. 2011, 12, 536. [CrossRef]

14. Pierre, D.; Baron, J.L.; Ma, X.; Sidari, F.P.; Wagener, M.M.; Stout, J.E. Water quality as a predictor of Legionella positivity of building water systems. Pathogens 2019, 8, 295. [CrossRef]

15. Ohno, A.; Kato, N.; Sakamoto, R.; Kimura, S.; Yamaguchi, K. Temperature-Dependent Parasitic Relationship between Legionella pneumophila and a Free-Living Amoeba (Acanthamoeba castellanii). Appl. Environ. Microbiol. 2008, 74, 4585-4588. [CrossRef] [PubMed]

16. Marciano-Cabral, F.; Cabral, G. Acanthamoeba spp. as agents of disease in humans. Clin. Microbiol. Rev. 2003, 16, 273-307. [CrossRef] [PubMed]

17. Sriram, R.; Shoff, M.; Booton, G.; Fuerst, P.; Visvesvara, G.S. Survival of Acanthamoeba cysts after desiccation for more than 20 years. J. Clin. Microbiol. 2008, 46, 4045-4048. [CrossRef]

18. Mazur, T.; Hadaś, E.; Iwanicka, I. The duration of the cyst stage and the viability and virulence of Acanthamoeba isolates. Trop. Med. Parasitol. 1995, 46, 106-108. [PubMed]

19. Kilvington, S. Moist-heat disinfection of Acanthamoeba cysts. Rev. Infect. Dis. 1991, 5, 418. [CrossRef]

20. Storey, M.V.; Winiecka-Krusnell, J.; Ashbolt, N.J.; Stenström, T.A. The efficacy of heat and chlorine treatment against thermotolerant Acanthamoebae and Legionellae. Scand. J. Infect. Dis. 2004, 36, 656-662. [CrossRef]

21. Thomas, V.; McDonnell, G.; Denyer, S.P.; Maillard, J.Y. Free-living amoebae and their intracellular pathogenic microorganisms: Risks for water quality. FEMS Microbiol. Rev. 2010, 34, 231-259. [CrossRef] [PubMed]

22. Mampel, J.; Spirig, T.; Weber, S.S.; Haagensen, J.A.; Molin, S.; Hilbi, H. Planktonic replication is essential for biofilm formation by Legionella pneumophila in a complex medium under static and dynamic flow conditions. Appl. Environ. Microbiol. 2006, 72, 2885-2895. [CrossRef]

23. Hindré, T.; Brüggemann, H.; Buchrieser, C.; Héchard, Y. Transcriptional profiling of Legionella pneumophila biofilm cells and the influence of iron on biofilm formation. Microbiology 2008, 154, 30-41. [CrossRef]

24. Pécastaings, S.; Bergé, M.; Dubourg, K.M.; Roques, C. Sessile Legionella pneumophila is able to grow on surfaces and generate structured monospecies biofilms. Biofouling 2010, 26, 809-819. [CrossRef] 
25. Stewart, C.R.; Muthye, V.; Cianciotto, N.P. Legionella pneumophila persists within biofilms formed by Klebsiella pneumoniae, Flavobacterium sp., and Pseudomonas fluorescens under dynamic flow conditions. PLoS ONE 2012, 7, 50560. [CrossRef]

26. Kives, J.; Orgaz, B.; Sanjosé, C. Polysaccharide differences between planktonic and biofilm-associated EPS from Pseudomonas fluorescens B52. Colloids Surf. B Biointerfaces 2006, 52, 123-127. [CrossRef] [PubMed]

27. Basson, A.; Flemming, L.A.; Chenia, H.Y. Evaluation of adherence, hydrophobicity, aggregation, and biofilm development of Flavobacterium johnsoniae-like isolates. Microb. Ecol. 2008, 55, 1-14. [CrossRef] [PubMed]

28. Wu, M.C.; Lin, T.L.; Hsieh, P.F.; Yang, H.C.; Wang, J.T. Isolation of genes involved in biofilm formation of a Klebsiella pneumoniae strain causing pyogenic liver abscess. PLoS ONE 2011, 6, e23500. [CrossRef] [PubMed]

29. Guerrieri, E.; Bondi, M.; Sabia, C.; de Niederhäusern, S.; Borella, P.; Messi, P. Effect of bacterial interference on biofilm development by Legionella pneumophila. Curr. Microbiol. 2008, 57, 532-536. [CrossRef] [PubMed]

30. Mallegol, J.; Duncan, C.; Prashar, A.; So, J.; Low, D.E.; Terebeznik, M.; Guyard, C. Essential roles and regulation of the Legionella pneumophila collagen-like adhesin during biofilm formation. PLoS ONE 2012, 7, e46462. [CrossRef] [PubMed]

31. Wright, J.B.; Ruseska, I.; Costerton, J.W. Decreased biocide susceptibility of adherent Legionella pneumophila. J. Appl. Bacteriol. 1991, 71, 531-538. [CrossRef]

32. Lin, Y.E.; Stout, J.E.; Yu, V.L. Controlling Legionella in hospital drinking water: An evidence-based review of disinfection methods. Infect. Control Hosp. Epidemiol. 2011, 32, 166-173. [CrossRef]

33. Liu, X.; Wang, J.; Liu, T.; Kong, W.; He, X.; Jin, Y.; Zhang, B. Effects of Assimilable Organic Carbon and free chlorine on bacterial growth in drinking water. PLoS ONE 2015, 10, e0128825. [CrossRef] [PubMed]

34. Williams, K.; Pruden, A.; Falkinham, J.O.; Edwards, M. Relationship between Organic Carbon and Opportunistic Pathogens in Simulated Glass Water Heaters. Pathogens 2015, 4, 355-372. [CrossRef] [PubMed]

35. Van der Kooij, D. Assimilable organic carbon as an indicator of bacterial regrowth. J. Am. Water Work. Assoc. 1992, 84, 57-65. [CrossRef]

36. Hammes, F.; Berger, C.; Köster, O.; Egli, T. Assessing biological stability of drinking water without disinfectant residuals in a full-scale water supply system. J. Water Supply Res. Technol. Aqua 2010, 59, 31-40. [CrossRef]

37. Volk, C.J.; LeChevallier, M.W. Assessing biodegradable organic matter. J. Am. Water Work. Assoc. AWWA 2000, 92, 64-76. [CrossRef]

38. Reeves, M.W.; Pine, L.; Hutner, S.H.; George, J.R.; Harrell, W.K. Metal requirements of Legionella pneumophila. J. Clin. Microbiol. 1981, 13, 688-695. [CrossRef]

39. States, S.J.; Conley, L.F.; Ceraso, M.; Stephenson, T.E.; Wolford, R.S.; Wadowsky, R.M.; McNamara, A.M.; Yee, R.B. Effects of metals on Legionella pneumophila growth in drinking water plumbing systems. Appl. Environ. Microbiol. 1985, 50, 1149-1154. [CrossRef]

40. Shang, C.; Blatchley, E.R. Differentiation and quantification of free chlorine and inorganic chloramines in aqueous solution by MIMS. Environ. Sci. Technol. 1999, 33, 2218-2223. [CrossRef]

41. Virto, R.; Mañas, P.; Álvarez, I.; Condon, S.; Raso, J. Membrane damage and microbial inactivation by chlorine in the absence and presence of a chlorine-demanding substrate. Appl. Environ. Microbiol. 2005, 71, 5022-5028. [CrossRef]

42. World Health Organization. Chlorine in Drinking-Water; World Health Organization: Geneva, Switzerland, 2003; p. 11. Available online: https:/ / www.who.int/water_sanitation_health/dwq/chlorine.pdf (accessed on 10 February 2021).

43. Cooper, I.R.; White, J.; Mahenthiralingam, E.; Hanlon, G.W. Long-term persistence of a single Legionella pneumophila strain possessing the mip gene in a municipal shower de-spite repeated cycles of chlorination. J. Hosp. Infect. 2008, 70, 154-159. [CrossRef] [PubMed]

44. García-Ávila, F.; Del Pino, L.F.; Bonifaz, G.A.; Zhindòn-Arévalo, C.; Ramos-Fernàndez, L.; Garcìa-Altamirano, D.; Sanchez, C. Effect of chlorine residual on copper pipes in drinking water systems. J. Eng. Sci. Technol. Rev. 2019, 12, 119-126. [CrossRef]

45. Cantor, A.F.; Park, J.K.; Vaiyavatjamai, P. The effect of chlorine on corrosion in drinking water systems. J. Am. Water Work. Assoc. AWWA 2003, 95, 112-123. [CrossRef]

46. Holm, T.R.; Schock, M.R. Potential effects of polyphosphate products on lead solubility in plumbing systems. J. Am. Water Work. Assoc. AWWA 1991, 83, 76. [CrossRef]

47. US EPA. EPA Drinking Water Guidance on Disinfection By-Products Advice Note No. 4. Version 2. Disinfection By-Products in Drinking Water. 2001. Available online: https://www.epa.ie/pubs/advice/drinkingwater/DrinkingWaterGuide4_v8.pdf (accessed on 10 February 2021).

48. Council Directive 98/83/EC of 3 November 1998 on the Quality of Water Intended for Human Consumption. 1998. Available online: https: / / eur-lex.europa.eu/legal-content/EN/TXT/?uri=celex\%3A31998L0083 (accessed on 10 February 2021).

49. Nikolau, A.D.; Golfinopoulos, S.K.; Arhonditsis, G.B.; Kolo-voyiannis, V.; Lekkas, T.D. Modeling the formation of chlorination by-products in river waters with different quality. Chemosphere 2004, 55, 409-420. [CrossRef]

50. Teksoy, A.; Alkan, U.; Başkaya, H.S. Influence of the treatment process combinations on the formation of THM species in water. Sep. Purif. Technol. 2008, 61, 447-454. [CrossRef]

51. Yan, M.; Wang, D.; Ma, X.; Ni, J.; Zhang, H. THMs precursor removal by an integrated process of ozonation and biological granular activated carbon for typical Northern China water. Sep. Purif. Technol. 2010, 72, 263-268. [CrossRef]

52. Liu, Z.; Wang, X.; Luo, Z.; Huo, M.; Wu, J.; Huo, H.; Yang, W. Removing of disinfection-by-products precursors from surface water by using magnetic graphene oxide. PLoS ONE 2015, 10, e0143819. [CrossRef] [PubMed] 
53. Dupuy, M.; Mazoua, S.; Berne, F.; Bodet, C.; Garrec, N.; Herbelin, P.; Menard-Szczebara, F.; Oberti, S.; Rodier, M.H.; Soreau, S.; et al. Efficiency of water disinfectants against Legionella pneumophila and Acanthamoeba. Water Res. 2011, 45, 1087-1094. [CrossRef] [PubMed]

54. Zhang, Z.; Mccann, C.; Hanrahan, J.; Jencson, A.; Joyce, D.; Fyffe, S.; Piesczynski, S.; Hawks, R.; Stout, J.E. Legionella control by chlorine dioxide in hospital water systems. J. Am. Water Work. Assoc. AWWA 2009, 101, 117-127. [CrossRef]

55. Marchesi, I.; Marchegiano, P.; Bargellini, A.; Cencetti, S.; Frezza, G.; Miselli, M.; Borella, P. Effectiveness of different methods to control legionella in the water supply: Ten-year experience in an Italian university hospital. J. Hosp. Infect. 2011, 77, 47-51. [CrossRef] [PubMed]

56. Casini, B.; Buzzigoli, A.; Cristina, M.L.; Spagnolo, A.M.; DelGiudice, P.; Brusaferro, S.; Poscia, A.; Moscato, U.; Valentini, P.; Baggiani, A.; et al. Long-term effects of hospital water network disinfection on Legionella and other waterborne bacteria in an Italian University Hospital. Infect. Control Hosp. Epidemiol. 2014, 35, 293-299. [CrossRef]

57. Chord, F.; Fascia, P.; Mallaval, F.; Cornillon, J.; Roesch, L.; Pozzetto, B.; Grattard, F.; Berthelot, P. Chlorine dioxide for Legionella spp. disinfection: A danger for cross-linked polyethylene pipes? J. Hosp. Infect. 2011, 78, 242-243. [CrossRef] [PubMed]

58. Yu, W.; Azhdar, B.; Anderson, D.; Reitberger, T.; Hassinen, J.; Hjertberg, T.; Gedde, U.W. Deterioration of polyethylene pipes exposed to water containing chlorine dioxide. Polym. Degrad. Stabil. 2011, 96, 790-797. [CrossRef]

59. Gan, W.; Huang, H.; Yang, X.; Peng, Z.; Chen, G. Emerging investigators series: Disinfection-by-products in mixed chlorine dioxide and chlorine water treatment. Environ. Sci. Water Res. Technol. 2016, 2, 838. [CrossRef]

60. World Health Organization. Monochloramine in Drinking-Water. 2004. Available online: https://www.who.int/water_ sanitation_health/water-quality/guidelines/chemicals/chloramine-background.pdf (accessed on 10 February 2021).

61. Alexander, M.T.; Waters, T.E.; Smith, G.A.; Wahman, D.G. New EPA Method to Determine Monochloramine Concentration in Drinking Water. In Proceedings of the 17th Annual EPA Drinking Water Workshop: Small System Challenges and Solutions, Covington, KY, USA, 1-3 September 2020.

62. Coniglio, M.A.; Ferrante, M.; Yassin, M.H. Preventing Healthcare-Associated Legionellosis: Results after 3 Years of Continuous Disinfection of Hot Water with Monochloramine and an Effective Water Safety Plan. Int. J. Environ. Res. Public Health 2018, 15, 1594. [CrossRef] [PubMed]

63. Jacangelo, J.G.; Olivieri, V.P.; Kawata, K. Investigating the mechanism of inactivation of Escherichia coli B by monochloramine. J. Am. Water Work. Assoc. 1991, 83, 80-87. [CrossRef]

64. Buse, H.Y.; Morris, B.J.; Struewing, I.T.; Szaboa, J.G. Chlorine and Monochloramine Disinfection of Legionella pneumophila Colonizing Copper and Polyvinyl Chloride Drinking Water Biofilms. Appl. Environ. Microbiol. 2019, 85, 02956-03018. [CrossRef]

65. Marchesi, I.; Paduano, S.; Frezza, G.; Sircana, L.; Vecchi, E.; Zuccarello, P.; Conti, G.; Ferrante, M.; Borella, P.; Bargellini, A. Safety and Effectiveness of Monochloramine Treatment for Disinfecting Hospital Water Networks. Int. J. Environ. Res. Public Health 2020, 17, 6116. [CrossRef]

66. Schramm, A.; Beer, D.; Gieseke, A.; Amann, R. Microenvironments and distribution of nitrifying bacteria in a membrane-bound biofilm. Environ. Microbiol. 2000, 2, 680-686. [CrossRef]

67. Lipponen, M.; Martikainen, P.; Vasara, R.; Servomaa, K.; Zacheus, O.; Kontro, M. Occurrence of nitrifiers and diversity of ammonia-oxidizing bacteria in developing drinking water biofilms. Water Res. 2004, 38, 4424-4434. [CrossRef]

68. Lieu, N.; Wolfe, R.; Means, E., III. Optimizing Chloramine Disinfection for the Control of Nitrification. J. Am. Water Work. Assoc. 1993, 85, 84-90. [CrossRef]

69. Nguyen, C.; Elfland, C.; Edwards, M. Impact of advanced water conservation features and new copper pipe on rapid chloramine decay and microbial regrowth. Water Res. 2012, 46, 611-621. [CrossRef] [PubMed]

70. Senevirathna, L.; Sathasivan, A.; Kastl, G. Forecasting the chloramine residual in service reservoirs from online measurement. Desalin. Water Treat. 2015, 57, 7943-7950. [CrossRef]

71. McGuire, M.J.; Wu, X.; Blute, N.K.; Askenaizer, D.; Qin, G. Prevention of nitrification using chlorite iron: Results of a demonstration project in Glendale, Calif. J. Am. Water Work. Assoc. AWWA 2009, 101, 47-59. [CrossRef]

72. Vikesland, P.; Ozekin, K.; Valentine, R. Effect of Natural Organic Matter on Monochloramine decomposition: Pathway Elucidation through the Use of Mass and Redox Balances. Environ. Sci. Technol. 1998, 32, 1409-1416. [CrossRef]

73. Proctor, C.R.; Dai, D.; Edwards, M.A.; Pruden, A. Interactive effects of temperature, organic carbon, and pipe material on microbiota composition and Legionella pneumophila in hot water plumbing systems. Microbiome 2017, 5, 130. [CrossRef]

74. Loveless, J.; Painter, H. The Influence of Metal Ion Concentrations and pH Value on the Growth of a Nitrosomonas Strain Isolated from Activated Sludge. Microbiology 1968, 52, 1-14. [CrossRef]

75. Wilczak, A. Chloramine Decay Rate: Factors and Research Needs. In Proceedings of the 2001 AWWA Annual Conference Proceedings, Washington, DC, USA, 17-21 June 2001.

76. Domingue, E.L.; Tyndall, R.L.; Mayberry, W.R.; Pancorbo, O.C. Effects of three oxidizing biocides on Legionella pneumophila serogroup 1. Appl. Environ. Microbiol. 1988, 54, 741-747. [CrossRef] [PubMed]

77. McGrane, W.K. Ozone, a study of the effects of biocides on Legionella pneumophila. Ind. Water Treat. 1995, 27, $28-32$.

78. Edelstein, P.H.; Whittaker, R.E.; Kreiling, R.L.; Howell, C.L. Efficacy of ozone in eradication of Legionella pneumophila from hospital plumbing fixtures. Appl. Environ. Microbiol. 1982, 44, 1330-1333. [CrossRef] [PubMed] 
79. Blanc, D.S.; Carrara, P.; Zanetti, G.; Francioli, P. Water disinfection with ozone, copper and silver ions, and temperature increase to control Legionella: Seven years of experience in a university teaching hospital. J. Hosp. Infect. 2005, 60, 69-72. [CrossRef] [PubMed]

80. Nogueira, R.; Utecht, K.U.; Exner, M.; Verstraete, W.; Rosenwinkel, K.H. Strategies for the reduction of Legionella in biological treatment systems. Water Sci. Technol. 2016, 4, 816-823. [CrossRef]

81. Richardson, S.D.; Thruston, A.D., Jr.; Caughran, T.V.; Chen, P.H.; Collette, T.W.; Floyd, T.L.; Schenck, K.M.; Lykins, B.W., Jr.; Sun, G.R.; Majetich, G. Identification of new ozone disinfection by products in drinking water. Environ. Sci. Technol. 1999, 33, 3368-3377. [CrossRef]

82. Mao, Y.; Wang, X.; Yang, H.; Wang, H.; Xie, Y.F. Effects of ozonation on disinfection byproduct formation and speciation during subsequent chlorination. Chemosphere 2014, 117, 515-520. [CrossRef] [PubMed]

83. Regulation (EU) No 528/2012 Concerning the Making Available on the Market and Use of Biocidal Products Evaluation of Active Substances Assessment. Report Hydrogen Peroxide. 2015. Available online: https:/ / echa.europa.eu/documents/10162/cad256 b7-8716-80f4-d091-c7bce0305d89 (accessed on 12 February 2021).

84. USEPA. Alternative Disinfectants and Oxidants Guidance Manual. Office of Water 815-R-99-014. 1999. Available online: https: / / nepis.epa.gov /Exe/tiff2png.exe/2000229L.PNG?-r+75+-g+7+D\%3A\%5CZYFILES\%5CINDEX\%20DATA\%5C9 5THRU99\%5CTIFF\%5C00001303\%5C2000229L.TIF (accessed on 12 February 2021).

85. Ditommaso, S.; Giacomuzzi, M.; Ricciardi, E.; Zotti, C.M. Efficacy of a Low Dose of Hydrogen Peroxide (Peroxy Ag+) for Continuous Treatment of Dental Unit Water Lines: Challenge Test with Legionella pneumophila Serogroup 1 in a Simulated Dental Unit Waterline. Int. J. Environ. Res. Public Health 2016, 13, 745. [CrossRef] [PubMed]

86. Casini, B.; Aquino, F.; Totaro, M.; Miccoli, M.; Galli, I.; Manfredini, L.; Giustarini, C.; Costa, A.L.; Tuvo, B.; Valentini, P.; et al. Application of Hydrogen Peroxide as an Innovative Method of Treatment for Legionella Control in a Hospital Water Network. Pathogens 2017, 6, 15. [CrossRef]

87. Landeen, L.K.; Moyasar, Y.; Gerba, C. Efficacy of copper and silver ions and reduced levels of free chlorine in inactivation of Legionella pneumophila. Appl. Environ. Microbiol. 1989, 55, 3045-3050. [CrossRef] [PubMed]

88. Rohr, U.; Senger, M.; Selenka, F.; Turley, R.; Wilhelm, M. Four years of experience with silver-copper ionization for control of Legionella in German University Hospital hot water plumbing system. Clin. Infect. Dis. 1999, 29, 1507-1511. [CrossRef] [PubMed]

89. Lin, Y.S.; Vidic, R.D.; Stout, J.E.; Yu, V.L. Negative effect of high pH on biocidal efficacy of copper and silver ions in controlling Legionella pneumophila. Appl. Environ. Microbiol. 2002, 68, 2711-2715. [CrossRef]

90. Pérez-Cachafeiro, S.; Mato, I.; Gonzàles Garcìa, I. Is copper-silver ionization safe and effective in controlling Legionella? J. Hosp. Infect. 2007, 67, 209-216. [CrossRef] [PubMed]

91. Zhang, H.; Andrews, S.A. Catalysis of copper corrosion products on chlorine decay and HAA formation in simulated distribution systems. Water Res. 2012, 46, 2665-2673. [CrossRef]

92. Liu, Z.; Stout, J.E.; Tedesco, L.; Boldin, M.; Hwang, C.; Yu, V.L. Efficacy of ultraviolet light in preventing Legionella colonization of a hospital water distribution system. Water Res. 1995, 29, 2275-2280. [CrossRef]

93. Kim, T.; Silva, J.L.; Chen, T.C. Effects of UV irradiation on selected pathogens in peptone water and on stainless steel and chicken meat. J. Food Prot. 2002, 65, 1142-1145. [CrossRef]

94. Charpentier, X.; Kay, E.; Schneider, D.; Shuman, H.A. Antibiotics and UV radiation induce competence for natural transformation in Legionella pneumophila. J. Bacteriol. 2011, 193, 1114-1121. [CrossRef] [PubMed]

95. Vilhunen, S.; Sarkka, J.; Silanpaa, M. Ultraviolet Light-Emitting Diodes in Water Disinfection. Environ. Sci. Pollut. Res. 2009, 16, 439-442. [CrossRef] [PubMed]

96. Chevremont, A.C.; Farnet, A.M.; Coulomb, B.; Boudenne, J.L. Effect of Coupled UV-A and UV-C LEDs on Both Microbiological and Chemical Pollution of Urban Wastewaters. Sci. Total Environ. 2012, 426, 304-310. [CrossRef]

97. De Carvalho, C.C.C.R. Biofilms: Microbial Strategies for Surviving UV Exposure. In Ultraviolet Light in Human Health, Diseases and Environment. Advances in Experimental Medicine and Biology; Ahmad, S., Ed.; Springer: Cham, Switzerland, 2017 ; p. 996.

98. Parkinson, J.; Baron, J.L.; Hall, B.; Bos, H.; Racine, P.; Wagener, M.M.; Stout, J.E. Point-of-use filters for prevention of health care-Acquired Legionnaires' disease: Field evaluation of a new filter product and literature review. Am. J. Infect. Control 2020, 48, 132-138. [CrossRef] [PubMed]

99. Molloy, S.L.; Ives, R.; Hoyt, A.; Taylor, R.; Rose, J.B. The use of copper and silver in carbon point-of-use filters for the suppression of Legionella throughput in domestic water systems. Appl. Microbiol. 2008, 104, 998-1007. [CrossRef]

100. Wu, C.C.; Ghosh, S.; Martin, K.J.; Pinto, A.J.; Denef, V.J.; Olson, T.M.; Love, N.G. The microbial colonization of activated carbon block point-of-use (PoU) filters with and without chlorinated phenol disinfection by-products. Environ. Sci. Water Res. Technol. 2017, 3, 830-843. [CrossRef]

101. Sheffer, P.J.; Stout, J.E.; Wagener, M.M.; Muder, R.R. Efficacy of new point-of-use water filter for preventing exposure to Legionella and waterborne bacteria. Am. J. Infect. Control 2005, 33, 20-25. [CrossRef] [PubMed]

102. Baron, J.L.; Peters, T.; Shafer, R.; MacMurray, B.; Stout, J.E. Field evaluation of a new point-of-use faucet filter for preventing exposure to Legionella and other waterborne pathogens in health care facilities. Am. J. Infect. Control 2014, 42, 1193-1196. [CrossRef]

103. Vonberg, R.P.; Sohr, D.; Bruderek, J.; Gastmeier, P. Impact of a silver layer on the membrane of tap water filters on the microbiological quality of filtered water. BMC Infect. Dis. 2008, 8, 133. [CrossRef] [PubMed] 
104. Oh, Y.; Noga, R.; Shanov, V.; Ryu, H.; Chandra, H.; Yadav, B.; Yadav, J.; Chae, S. Electrically heatable carbon nanotube point-of-use filters for effective separation and in-situ inactivation of Legionella pneumophila. Chem. Eng. J. 2019, 366, 21-26. [CrossRef] [PubMed]

105. Oyanedel-Craver, V.A.; Smith, J.A. Sustainable Colloidal-Silver-Impregnated Ceramic Filter for Point-of-Use Water Treatment. Environ. Sci. Technol. 2008, 42, 927-933. [CrossRef]

106. Chaftar, N.; Girardot, M.; Quellard, N.; Labanowski, J.; Ghrairi, T.; Hani, K.; Frère, J.; Imbert, C. Activity of six essential oils extracted from tunisian plants against Legionella pneumophila. Chem. Biodivers. 2015, 12, 1565-1574. [CrossRef]

107. Chang, C.W.; Chang, W.L.; Chang, S.T.; Cheng, S.S. Antibacterial activities of plant essential oils against Legionella pneumophila. Water Res. 2008, 42, 278-286. [CrossRef] [PubMed]

108. Chang, C.W.; Chang, W.L.; Chang, S.T. Influence of pH on bioactivity of cinnamon oil against Legionella pneumophila and its disinfection efficacy in hot springs. Water Res. 2008, 42, 5022-5030. [CrossRef]

109. Ceylan, O.; Turasay, B. Removing Legionella pneumophila and biofilms from water supply systems using plant essential oils. J. Water Sanit. Hyg. Dev. 2017, 7, 67-73. [CrossRef]

110. Mondello, F.; Girolamo, A.; Scaturro, M.; Ricci, M.L. Determination of Legionella pneumophila susceptibility to Melaleuca alternifolia Cheel (tea tree) oil by an improved broth micro-dilution method under vapour controlled conditions. J. Microbiol. Methods 2009, 77, 243-248. [CrossRef]

111. Buchoux, S.; Lai-Kee-Him, J.; Garnier, M.; Tsan, P.; Besson, F.; Brisson, A.; Dufourc, E.J. Surfactin-Triggered Small Vesicle Formation of Negatively Charged Membranes: A Novel Membrane-Lysis Mechanism. Biophys J. 2008, 95, 3840-3849. [CrossRef]

112. Loiseau, C.; Portier, E.; Corre, M.H.; Schlusselhuber, M.; Depayras, S.; Berjeaud, J.M.; Verdon, J. Highlighting the Potency of Biosurfactants Produced by Pseudomonas Strains as Anti-Legionella Agents. Biomed. Res. Int. 2018, 2018, 1-15. [CrossRef]

113. Mora, I.; Cabrefiga, J.; Montesinos, E. Cyclic lipopeptide biosynthetic genes and products, and inhibitory activity of plantassociated Bacillus against phytopathogenic bacteria. PLoS ONE 2015, 10, e0127738. [CrossRef] [PubMed]

114. Loiseau, C.; Schlusselhuber, M.; Bigot, R.; Bertaux, J.; Berjeaud, J.M.; Verdon, J. Surfactin from Bacillus subtilis displays an unexpected anti-Legionella activity. Appl. Microbiol. Biotechnol. 2015, 99, 5083-5093. [CrossRef] [PubMed]

115. Fuochi, V.; Coniglio, M.A.; Laghi, L.; Rescifina, A.; Caruso, M.; Stivala, A.; Furneri, P.M. Metabolic Characterization of Supernatants Produced by Lactobacillus spp. With in vitro Anti-Legionella Activity. Front. Microbiol. 2019, 10, 1403. [CrossRef]

116. Cavallaro, A.; Taheri, S.; Vasilev, K. Responsive and "smart" antibacterial surfaces: Common approaches and new developments. Biointerphases 2014, 9, 029005. [CrossRef]

117. Susarrey-Arce, A.; Sorzabal-Bellido, I.; Oknianska, A.; McBride, F.; Beckett, A.J.; Gardeniers, J.G.E.; Raval, R.; Tiggelaar, R.M.; Diaz Fernandez, Y.A. Bacterial viability on chemically modified silicon nanowire arrays. J. Mater. Chem. B 2016, 4, 3104-3112. [CrossRef] [PubMed]

118. Sciuto, E.L.; Filice, S.; Coniglio, M.A.; Faro, G.; Gradon, L.; Galati, C.; Spinella, N.; Libertino, S.; Scalese, S. Antimicrobial s-PBC Coatings for Innovative Multifunctional Water Filters. Molecules 2020, 25, 5196. [CrossRef] [PubMed]

119. Centers for Disease Control and Prevention (CDC). Sampling Procedure and Potential Sampling Sites. Protocol for Collecting Environmental Samples for Legionella Culture during a Cluster or Outbreak Investigation or When Cases of Disease May Ba Associated with a Facility. 2015. Available online: https:/ / www.cdc.gov/legionella/downloads/cdc-sampling-procedure.pdf (accessed on 12 February 2021).

120. U.K. Environmental Agency. The Determination of Legionella Bacteria in Waters and Other Environmental Samples-Part 1-Rationale of Surveying and Sampling-Methods for the Examination of Waters and Associated Materials. 2005. Available online: https://www.gov.uk/government/uploads/system/uploads/attachment_data/file/316814/book_200_1028650.pdf (accessed on 12 February 2021).

121. Bartram, J.; Chartier, Y.; Lee, J.V.; Pond, K.; Surman-Lee, S. Legionella and the Prevention of Legionellosis; World Health Organization: Geneva, Switzerland, 2007.

122. Delia, S.; Laganà, P.; Minutoli, E. Occurrence of Legionella in beach shower facilities. J. Prev. Med. Hyg. 2007, 48, 114-117. [PubMed]

123. Laganà, P.; Gambuzza, M.E.; Delia, S. Legionella risk assessment in cruise ships and ferries. Ann. Agric. Environ. Med. 2017, 24, 276-282. [CrossRef] [PubMed]

124. Coniglio, M.A.; Andolfi, N.; Faro, G.; Pellegrino, M.B.; Sgalambro, A.; D’Aquila, G.; Spina, A.; Melada, S. Continuous Disinfection by Monochloramine on Domestic Hot Water System of Health-care Facilities for the Control of Legionella Contamination in Italy. J. Health Sci. 2015, 3, 11-17.

125. Coniglio, M.A.; Strano, V.; D’Angelo, S.; Guercio, M.A.; Spada, R.; Melada, S. Effectiveness of in-Situ Generated Monochloramine for the Control of Legionella in a Real Industrial Cooling Tower. Glob. J. Med. Res. K Interdiscip. 2015, 15, 9-15.

126. Coniglio, M.A. Evaluation of the Effectiveness of a 4-Months Continuous Injection of a Gas Mixture $\left(\mathrm{CO}_{2}\right.$ and Inert Gases) on Legionella Contamination of a Hot Water Distribution System. Health 2015, 7, 819-823. [CrossRef]

127. Kool, J.L.; Bergmire-Sweat, D.; Butler, J.C.; Brown, E.W.; Peabody, D.J.; Massi, D.S.; Carpenter, J.C.; Pruckler, J.M.; Benson, R.F.; Fields, B.S. Hospital characteristics associated with colonization of water systems by Legionella and risk of nosocomial legionnaires' disease: A cohort study of 15 hospitals. Infect. Control Hosp. Epidemiol. 1999, 20, 798-805. [CrossRef] [PubMed]

128. Bentham, R. Risk assessment for Legionella in building water systems. Environ. Health 2003, 3, 20. 
129. Napoli, C.; Iatta, R.; Fasano, F.; Marsico, T.; Montagna, M.T. Variable bacterial load of Legionella spp. in a hospital water system. Sci. Total Environ. 2009, 408, 242-244. [CrossRef]

130. Casini, B.; Baggiani, A.; Totaro, M.; Mansi, A.; Costa, A.L.; Aquino, F.; Miccoli, M.; Valentini, P.; Bruschi, F.; Lopalco, P.L.; et al. Detection of viable but non-culturable legionella in hospital water network following monochloramine disinfection. J. Hosp. Infect. 2018, 98, 46-52. [CrossRef]

131. Ducret, A.; Chabalier, M.; Dukan, S. Characterization and resuscitation of 'non-culturable' cells of Legionella pneumophila. BMC Microbiol. 2014, 14, 1-10. [CrossRef]

132. Dietersdorfer, E.; Kirschner, A.; Schrammel, B.; Ohradanova-Repic, A.; Stockinger, H.; Sommer, R.; Walochnik, J.; Cervero-Aragó, S. Starved viable but non-culturable (VBNC) Legionella strains can infect and replicate in amoebae and human macrophages. Water Res. 2018, 141, 428-438. [CrossRef]

133. López-Gálvez, F.; Tudela, J.A.; Allende, A.; Gil, M.I. Microbial and chemical characterization of commercial washing lines of fresh produce highlights the need for process water control. Innov. Food Sci. Emerg. Technol. 2019, 51, 211-219. [CrossRef]

134. Kirschner, A.K.T. Determination of viable legionellae in engineered water systems: Do we find what we are looking for? Water Res. 2016, 93, 276-288. [CrossRef]

135. Baudart, J.; Guillaume, C.; Mercier, A.; Lebaron, P.; Binet, M. Rapid quantification of viable Legionella in nuclear cooling tower waters using filter cultivation, fluorescent in situ hybridization and solidphase cytometry. J. Appl. Microbiol. 2015, 118, 1238-1249. [CrossRef]

136. Allegra, S.; Girardot, F.; Grattard, F.; Berthelot, P.; Helbig, J.H.; Pozzetto, B.; Riffard, S. Evaluation of an immunomagnetic separation assay in combination with cultivation to improve Legionella pneumophila serogroup 1 recovery from environmental samples. J. Appl. Microbiol. 2011, 110, 952-961. [CrossRef] [PubMed]

137. Pinto, P.; Santos, M.A.; Chambel, L. Thirty years of viable but nonculturable state research: Unsolved molecular mechanisms. Crit. Rev. Microbiol. 2015, 41, 61-76. [CrossRef] [PubMed]

138. Strauber, H.; Muller, S. Viability states of bacteria-specific mechanisms of selected probes. Cytom. A 2010, 77, 623-634. [CrossRef]

139. Stocks, S.M. Mechanism and use of the commercially available viability stain, BacLight. Cytom. A 2004, 61, 189-195. [CrossRef] [PubMed]

140. Jepras, R.I.; Carter, J.; Pearson, S.C.; Paul, F.E.; Wilkinson, M.J. Development of a robust flow cytometric assay for determining numbers of viable bacteria. Appl. Environ. Microbiol. 1995, 61, 2696-2701. [CrossRef]

141. Tholozan, J.L.; Cappelier, J.M.; Tissier, J.P.; Delattre, G.; Federighi, M. Physiological Characterization of Viable-but-Nonculturable Campylobacter jejuni Cells. Appl. Environ. Microbiol. 1999, 65, 1110-1116. [CrossRef] [PubMed]

142. Alonso, C. Tips and tricks for high quality MAR-FISH preparations: Focus on bacterioplankton analysis. Syst. Appl. Microbiol. 2012, 35, 503-512. [CrossRef] [PubMed]

143. Bakker, E.P.; Rottenberg, H.; Caplan, S.R. An estimation of the light-induced electrochemical potential difference of protons across the membrane of Halobacterium halobium. Biochim. Biophys. Acta 1976, 440, 557-572. [CrossRef]

144. Wang, Y.; Claeys, L.; van der Ha, D.; Verstraete, W.; Boon, N. Effects of chemically and electrochemically dosed chlorine on Escherichia coli and Legionella beliardensis assessed by flow cytometry. Appl. Microbiol. Biotechnol. 2010, 87, 331-334. [CrossRef]

145. Su, X.; Sun, F.; Wang, Y.; Hashmi, M.Z.; Guo, L.; Ding, L.; Shen, C. Identification, characterization and molecular analysis of the viable but nonculturable Rhodococcus biphenylivorans. Sci. Rep. 2015, 5, 18590. [CrossRef]

146. Kirschner, A.K.; Rameder, A.; Schrammel, B.; Indra, A.; Farnleitner, A.H.; Sommer, R. Development of a new CARD-FISH protocol for quantification of Legionella pneumophila and its application in two hospital cooling towers. J. Appl. Microbiol. 2012, 112, 1244-1256. [CrossRef] [PubMed]

147. Karner, M.; Fuhrman, J.A. Determination of active Marine bacterioplankton: A comparison of universal 16S rRNA probes, autoradiography, and nucleoid staining. Appl. Environ. Microbiol. 1997, 63, 1208-1213. [CrossRef]

148. Moreno, Y.; Moreno-Mesonero, L.; García-Hernández, J. DVC-FISH to identify potentially pathogenic Legionella inside free-living amoebae from water sources. Environ. Res. 2019, 176, 108521. [CrossRef]

149. Delgado-Viscogliosi, P.; Solignac, L.; Delattre, J. Viability PCR, a Culture-Independent Method for Rapid and Selective Quantification of Viable Legionella pneumophila Cells in Environmental Water Samples. Appl. Environ. Microbiol. 2009, 75, 3502-3512. [CrossRef]

150. Boss, R.; Baumgartner, A.; Kroos, S.; Blattner, M.; Fretz, R.; Moor, D. Rapid detection of viable Legionella pneumophila in tap water by a qPCR and RT-PCR-based method. J. Appl. Microbiol. 2018, 125, 1216-1225. [CrossRef]

151. Dusserre, E.; Ginevra, C.; Hallier-Soulier, S.; Vandenesch, F.; Festoc, G.; Etienne, J.; Jarraud, S.; Molmeret, M. A PCR-Based Method for Monitoring Legionella pneumophila in Water Samples Detects Viable but Noncultivable Legionellae That Can Recover Their Cultivability. Appl. Environ. Microbiol. 2008, 74, 4817-4824. [CrossRef]

152. Truchado, P.; Gil, M.I.; Larrosa, M.; Allende, A. Detection and Quantification Methods for Viable but Non-culturable (VBNC) Cells in Process Wash Water of Fresh-Cut Produce: Industrial Validation. Front. Microbiol. 2020, 11, 673. [CrossRef]

153. Zhao, L.; Lv, X.; Cao, X.; Zhang, J.; Gu, X.; Zeng, H.; Wang, L. Improved quantitative detection of VBNC Vibrio parahaemolyticus using immunomagnetic separation and PMAxx-qPCR. Food Control 2020, 110, 106962. [CrossRef]

154. Cesewski, E.; Johnson, B.N. Electrochemical biosensors for pathogen detection. Biosens. Bioelectron. 2020, 159, 112214. [CrossRef]

155. Huertas, C.S.; Calvo-Lozano, O.; Mitchell, A.; Lechuga, L.M. Advanced Evanescent-Wave Optical Biosensors for the Detection of Nucleic Acids: An Analytic Perspective. Front. Chem. 2019, 7, 724. [CrossRef] 
156. Pardoux, É.; Boturyn, D.; Roupioz, Y. Antimicrobial Peptides as Probes in Biosensors Detecting Whole Bacteria: A Review. Molecules 2020, 25, 1998. [CrossRef]

157. Mannoor, M.S.; Zhang, S.; Link, A.J.; McAlpine, M.C. Electrical detection of pathogenic bacteria via immobilized antimicrobial peptides. Proc. Natl. Acad. Sci. USA 2010, 107, 19207-19212. [CrossRef]

158. Sciuto, E.L.; Santangelo, M.F.; Villaggio, G.; Sinatra, F.; Bongiorno, C.; Nicotra, G.; Libertino, S. Photo-physical characterization of fluorophore $\mathrm{Ru}(\mathrm{bpy}) 32+$ for optical biosensing applications. Sens. Biosens. Res. 2015, 6, 65-71.

159. Sciuto, E.L.; Villaggio, G.; Santangelo, M.F.; Laudani, S.; Federico, C.; Saccone, S.; Sinatra, F.; Libertino, S. Study of a miniaturizable system for optical sensing application to human cells. Appl. Sci. 2019, 9, 975. [CrossRef]

160. Sciuto, E.L.; Petralia, S.; Calabrese, G.; Conoci, S. An integrated biosensor platform for extraction and detection of nucleic acids. Biotechnol. Bioeng. 2020, 117, 1554-1561. [CrossRef] [PubMed]

161. Santangelo, M.F.; Pagano, R.; Lombardo, S.; Sciuto, E.; Sanfilippo, D.; Fallica, G.; Sinatra, F.; Libertino, S. Silicon photomultipliers applications to biosensors. In Proceedings of the Silicon Photonics IX, San Francisco, CA, USA, 3-5 February 2014.

162. Petralia, S.; Sciuto, E.L.; Mirabella, S.; Di Pietro, M.L.; Zimbone, M.; Conoci, S. An Innovative Chemical Strategy for PCR-free Genetic Detection of Pathogens by an Integrated Electrochemical Biosensor. Analyst 2017, 142, 2090-2093. [CrossRef]

163. Petralia, S.; Sciuto, E.L.; Messina, M.A.; Mirabella, S.; Scandurra, A.; Priolo, F.; Conoci, S. Miniaturized and Multi-Purpose Electrochemical Sensing Device based on thin Ni Oxides. Sens. Actuators B Chem. 2018, 263, 10-19. [CrossRef]

164. Massad-Ivanir, N.; Shtenberg, G.; Raz, N.; Gazenbeek, C.; Budding, D.; Bos, M.P.; Segal, E. Porous Silicon-Based Biosensors: Towards Real-Time Optical Detection of Target Bacteria in the Food Industry. Sci. Rep. 2016, 6, 38099. [CrossRef]

165. Bartram, J.; Corrales, L.; Davison, A.; Deere, D.; Drury, D.; Gordon, B.; Howard, G.; Rinehold, A.; Stevens, M. Water Safety Plan Manual: Step-by-Step Risk Management for Drinking-Water Suppliers; World Health Organization: Geneva, Switzerland, 2009. Available online: https:/ /apps.who.int/iris/bitstream/handle/10665/75141/9789241562638_eng.pdf?sequence=1\&isAllowed=y (accessed on 12 February 2021).

166. ASHRAE. Legionellosis: Risk Management for Building Water Systems; ASHRAE Standard 188; ASHRAE: Atlanta, GA, USA, 2015. Available online: https:/ / www.ashrae.org/technical-resources/bookstore/ansi-ashrae-standard-188-2018-legionellosis-riskmanagement-for-building-water-systems (accessed on 12 February 2021). 